\title{
Article \\ Meta-Analysis of Heifer Traits Identified Reproductive Pathways in Bos indicus Cattle
}

\author{
Muhammad S. Tahir ${ }^{1}$, Laercio R. Porto-Neto ${ }^{2}$, Cedric Gondro ${ }^{3}$, Olasege B. Shittu ${ }^{1}$, Kimberley Wockner ${ }^{1}$, \\ Andre W. L. Tan $\left.{ }^{1} \mathbb{(}\right)$, Hugo R. Smith ${ }^{1}$, Gabriela C. Gouveia ${ }^{4}{ }^{\circledR}$, Jagish Kour ${ }^{1}$ and Marina R. S. Fortes ${ }^{1, *}$ \\ 1 School of Chemistry and Molecular Bioscience, The University of Queensland Australia, \\ Brisbane, QLD 4072, Australia; m.tahir@uqconnect.edu.au (M.S.T.); b.olasege@uqconnect.edu.au (O.B.S.); \\ k.wockner@uq.edu.au (K.W.); weiliangandre.tan@uqconnect.edu.au (A.W.L.T.); \\ h.rosssmith@uqconnect.edu.au (H.R.S.); jagishkour@uq.net.au (J.K.) \\ 2 Commonwealth Scientific and Industrial Research Organization, Brisbane, QLD 4072, Australia; \\ laercio.portoneto@csiro.au \\ 3 Department of Animal Science, Michigan State University, East Lansing, MI 48824, USA; gondroce@msu.edu \\ 4 Animal Science Department, Veterinary School, Federal University of Minas Gerais, \\ Belo Horizonte 31270-901, Brazil; gabrielacgouveia@hotmail.com \\ * Correspondence: m.fortes@uq.edu.au; Tel.: +61-7-336-54258
}

check for updates

Citation: Tahir, M.S.; Porto-Neto, L.R.; Gondro, C.; Shittu, O.B.;

Wockner, K.; Tan, A.W.L.; Smith, H.R.; Gouveia, G.C.; Kour, J.; Fortes, M.R.S. Meta-Analysis of Heifer Traits Identified Reproductive Pathways in Bos indicus Cattle. Genes 2021, 12, 768. https://doi.org/10.3390/ genes12050768

Academic Editor: Ottmar Distl

Received: 6 April 2021

Accepted: 13 May 2021

Published: 18 May 2021

Publisher's Note: MDPI stays neutral with regard to jurisdictional claims in published maps and institutional affiliations.

Copyright: (c) 2021 by the authors. Licensee MDPI, Basel, Switzerland. This article is an open access article distributed under the terms and conditions of the Creative Commons Attribution (CC BY) license (https:// creativecommons.org/licenses/by/ $4.0 /)$.
Abstract: Fertility traits measured early in life define the reproductive potential of heifers. Knowledge of genetics and biology can help devise genomic selection methods to improve heifer fertility. In this study, we used 2400 Brahman cattle to perform GWAS and multi-trait meta-analysis to determine genomic regions associated with heifer fertility. Heifer traits measured were pregnancy at first mating opportunity (PREG1, a binary trait), first conception score (FCS, score 1 to 3 ) and rebreeding score (REB, score 1 to 3.5). The heritability estimates were 0.17 (0.03) for PREG1, 0.11 (0.05) for FCS and $0.28(0.05)$ for REB. The three traits were highly genetically correlated $(0.75-0.83)$ as expected. Meta-analysis was performed using SNP effects estimated for each of the three traits, adjusted for standard error. We identified 1359 significant SNPs ( $p$-value $<9.9 \times 10^{-6}$ at FDR < 0.0001) in the multi-trait meta-analysis. Genomic regions of $0.5 \mathrm{Mb}$ around each significant SNP from the meta-analysis were annotated to create a list of 2560 positional candidate genes. The most significant SNP was in the vicinity of a genomic region on chromosome 8, encompassing the genes SLC44A1, FSD1L, FKTN, TAL2 and TMEM38B. The genomic region in humans that contains homologs of these genes is associated with age at puberty in girls. Top significant SNPs pointed to additional fertilityrelated genes, again within a $0.5 \mathrm{Mb}$ region, including ESR2, ITPR1, GNG2, RGS9BP, ANKRD27, TDRD12, GRM1, MTHFD1, PTGDR and NTNG1. Functional pathway enrichment analysis resulted in many positional candidate genes relating to known fertility pathways, including GnRH signaling, estrogen signaling, progesterone mediated oocyte maturation, cAMP signaling, calcium signaling, glutamatergic signaling, focal adhesion, PI3K-AKT signaling and ovarian steroidogenesis pathway. The comparison of results from this study with previous transcriptomics and proteomics studies on puberty of the same cattle breed (Brahman) but in a different population identified 392 genes in common from which some genes-BRAF, GABRA2, GABR1B, GAD1, FSHR, CNGA3, PDE10A, SNAP25, ESR2, GRIA2, ORAI1, EGFR, CHRNA5, VDAC2, ACVR2B, ORAI3, CYP11A1, GRIN2A, ATP2B3, CAMK2A, PLA2G, CAMK2D and MAPK3-are also part of the above-mentioned pathways. The biological functions of the positional candidate genes and their annotation to known pathways allowed integrating the results into a bigger picture of molecular mechanisms related to puberty in the hypothalamus-pituitary-ovarian axis. A reasonable number of genes, common between previous puberty studies and this study on early reproductive traits, corroborates the proposed molecular mechanisms. This study identified the polymorphism associated with early reproductive traits, and candidate genes that provided a visualization of the proposed mechanisms, coordinating the hypothalamic, pituitary, and ovarian functions for reproductive performance in Brahman cattle.

Keywords: GWAS; meta-analysis; gene ontology; Bos indicus; Brahman cattle; fertility; puberty; hypothalamus; pituitary; ovary; biological pathways 


\section{Introduction}

Early reproductive traits contribute to the fertility of female beef cattle. These traits affect the cows' lifetime reproductive capacity, which has a flow-on repercussion to farm economics [1,2]. Puberty, an early reproductive trait, is delayed in Brahman cattle (a composite cattle breed largely descended from Bos indicus cattle) as compared to other beef breeds, and as a consequence the first calving event is also delayed [1,3]. Timing of puberty, establishment of pregnancy and resumption of post-calving estrous cycles are important benchmarks of productivity for beef cows [1]. This criterion of beef productivity is dependent on early reproductive traits, which rely on the biological phenomenon of puberty.

Attainment of puberty is a complex coordination between ovaries, hypothalamus and pituitary through negative and positive feedback mechanisms. Ovaries through estrogen signaling maintain negative feedback on the hypothalamus to prevent secretion of GnRH before puberty $[4,5]$. At puberty, the negative feedback of estrogen on hypothalamus is reverted to positive feedback, which allows GnRH production. Kisspeptin, GABAergic, glutamatergic and cholinergic neurons coordinate with GnRH neurons [6-9]. These neurons, through their neurotransmitters, activate signaling cascades including calcium signaling, cAMP signaling and MAPK signaling in GnRH neurons to secrete GnRH [7,10-12]. Signaling by GnRH through GnRH receptor (GNRHR) causes the pituitary to release FSH and LH by activating Calcium and cAMP pathways $[13,14]$. In ovaries, FSH facilitates follicular growth, while LH is involved in maturation of oocyte and ovulation.

We included three early reproductive traits in our analyses: pregnancy at first mating opportunity (PREG1, a binary trait), first conception score (FCS, score 1-3) and rebreeding score based on the outcome of the first two mating opportunities (REB, score 1-3.5). These traits are influenced by the biological phenomenon of puberty and by the length of postpartum anestrous. Studying these traits can reveal the biological basis of early puberty in beef cows. Early reproductive traits are usually heritable to a low-to-moderate extent ( $\sim 0.1$ to $0.5)$, which indicates the influence of genetics and environmental factors such as location, breed and nutrition on these traits [15]. A study of PREG1 in Nellore cattle, estimated a heritability of 0.18 and reported 101 associated SNPs with a $p$-value $<0.001$ and a false discovery rate value of 0.53 [16]. Post-partum anestrous interval (PPAI) and post-partum ovulation before weaning (PW), which are traits based on observing the resumption of the cycle after the first calving (biologically similar to REB in this study), have reported heritabilities of 0.26 and 0.08 in Brahman cattle, respectively [17]. A trait termed "early pregnancy" in Nellore cattle, which is similar to FCS in this study, has an estimated heritability of 0.30 [18]. These studies indicate that early reproductive traits do have a heritable component that can be explored in cattle breeding programs. However, previous GWAS revealed their complex nature: many associated polymorphisms with small effects. Small effects might be ignored in GWAS when the threshold for SNP significance is set at very low $p$-values because of multiple tests [19-21]. This issue results in missing heritability which is often observed for complex traits, especially when the heritability is not high [22]. Meta-analysis of complex traits can address the problem of small SNP effects [19-21], as it considers SNP effects across traits or populations, looking for concordant results [23]. Meta-analyses have identified higher numbers of significant SNPs for reproductive traits, as compared to single-trait GWAS [24,25]. In this context, using three traits in a meta-analysis might be more powerful than looking at PREG1, FCS and REB separately.

\section{Materials and Methods}

\subsection{Phenotypes}

The data for this study were obtained from the "Female Fertility PhenoBank" (L.GEN.1710) project funded by Meat and Livestock Australia (MLA). This project maintains a database of reproductive phenotypes recorded in female cattle, with a focus on tropical beef breeds raised in northern Australia. Data from previous genomics projects and new industry partners were curated and gathered in PhenoBank, which is an ongoing effort 
to create a robust platform for cattle genomics research. We selected, curated and combined data from 2400 Brahman cows, for which we defined new phenotypes. These cow records were sourced from the Cooperative Research Center for Beef Genetics Technologies (or Beef CRC), the Northern Territory DITT breeding herd and the Kamilaroi herd investigated in a CSIRO-led project. The datasets contained enough information for us to define phenotypes based on the reproductive performance records of the first two mating seasons of each cow's life. These phenotypes are easy to measure traits that can, in the future, be adopted by the beef industry; they do not require intensive measurement. The three early-in-life reproductive traits obtained from PhenoBank were: PREG1, FCS, and REB as per Table 1. The number of animals for each trait category, and in each dataset (see Table S1), were the numbers available after data curation based on the availability of accurate pregnancy records for contemporary groups of cows.

Table 1. Scoring criteria of early reproductive traits in Brahman heifers.

\begin{tabular}{|c|c|c|c|}
\hline No. & Trait & Score & Scoring Criteria \\
\hline \multirow{2}{*}{1} & \multirow{2}{*}{ PREG1 } & 1 & Not pregnant as a result of the first mating opportunity $(n=600)$ \\
\hline & & 2 & Pregnant as a result of the first mating opportunity $(n=1719)$ \\
\hline \multirow{3}{*}{2} & \multirow{3}{*}{ FCS } & 1 & Never conceived up to 36 months of age $(n=429)$ \\
\hline & & 2 & Conceived between 29 and 36 months of age $(n=436)$ \\
\hline & & 3 & Conceived before 29 months of age $(n=1150)$ \\
\hline \multirow{4}{*}{3} & \multirow{4}{*}{ REB } & 1 & Not pregnant as a result of the first two mating opportunities $(n=153)$ \\
\hline & & 2 & Pregnant as a result of the second mating opportunity, but not the first $(n=550)$ \\
\hline & & 2.5 & Pregnant as a result of the first mating opportunity, not the second $(n=506)$ \\
\hline & & 3.5 & Pregnant twice, as a result of the first two mating opportunities $(n=326)$ \\
\hline
\end{tabular}

PREG1: Pregnancy outcome after first mating chance. FCS: first conception score. REB: rebreeding score.

\subsection{Genotypes and Imputation}

Medium-density genotypes of selected cows were available from PhenoBank. The genotypes of the Beef CRC cows were already available and incorporated into PhenoBank. These cows were genotyped with a medium density SNP chip, Bovine50K v.1 [17]. Genotyping of NT DITT cows and Kamilaroi cows was recently completed by NEOGEN Australia with funding from the PhenoBank. NT DITT cows were genotyped with the mediumdensity GGP Bovine50K SNP chip for beef, while Kamilaroi cows were genotyped with the GGP TropBeef 35K SNP chip. Medium-density genotypes of these datasets were imputed to high-density, separately, as described below.

A reference panel of 546 Brahman animals genotyped with the BovineHD (770K) SNP chip was used to impute genotypes from the medium-density SNP panels. A combination of Eagle v2.4.1 [26] and Minimac3 [27] was used for imputation. Briefly, both, high and medium-density genotypes were mapped with the same genetic marker map (ARS-UCD 1.2 HD 2018). The genotypes of the high and medium-density datasets were first passed through quality control and SNPs with a call rate $>0.85$ and MAF $>0.05$ were retained for analyses. Then, all genotype sets were split into individual chromosomes, one chromosome per file, using PLINK [28]. Individual chromosome files of high and medium datasets were phased, separately, using Eagle v2.4.1. Then, Minimac3 was used to impute individually phased chromosomes of medium-density datasets to high-density using individually phased chromosomes of the reference panel. Individually imputed chromosomes of each dataset were converted to "ped. map." format using vcf-tools [29], and then merged using PLINK. For quality control, imputed SNPs with allelic correlation $\left(R^{2}\right)$ value less than 0.4 were discarded [30]. As a result, 718,464 SNPs were retained for the beef CRC dataset, 719,140 SNPs remained for Kamilaroi, and 689,037 SNPs remained for the NT DITT dataset. These datasets were then combined for analyses of each trait. The combined genotypes datasets for each trait were passed through a final quality control (SNPs with a call rate $<0.9$ and MAF $<0.05$ were discarded) to get over 500,000 SNPs for the combined dataset. As the 
number of animals differed for each trait, so did the SNPs that passed the quality control (587,900 SNPs for PREG1, 584,510 SNPs for FCS, and 584,344 SNPs for REB).

\subsection{Fixed Effects}

Each phenotype dataset had its own fixed effects to account for contemporary group effects, as these were separate herds raised independently. Phenotypes of individual datasets were adjusted for their own significant fixed effects, separately, using SNP $\mathcal{E}$ Variation Suite v8.x Golden Helix [31]. Contemporary groups were defined by farm location (animals raised together on the same farm), birth year, which informs the cow crop (year) and birth month class (Aug to Nov = Class A; Dec to April = Class B). For the Beef CRC dataset, farm, cow crop and birth month class were used as fixed effects, separately. For the NT DITT dataset, cow crop and birth month class were used as fixed effects, separately. For the Kamilaroi dataset, cow crop was used as a fixed effect. The distribution of animals in contemporary groups is provided in Table S2. A previously reported method to adjust for fixed effects was used as follows [32,33]:

$$
y=X_{1} \beta_{1}+X_{2} \beta_{2}+\ldots X_{n} \beta_{n}+Z \mu+e
$$

where $X_{1 \cdot . n}$ are vectors of $1 . . n$ fixed effects, $\beta_{1 \cdot . n}$ are estimates of $1 . . n$ fixed effects. $Z$ is an incidence matrix of random polygenic effects; $\mu$ is the estimate of random polygenic effects $\sim \mathrm{N}\left(0, G \sigma \mu^{2}\right)$ where $\mathrm{G}$ is the genomic relationship matrix (GRM) based on all SNP variants. Residual is represented as " $\mathrm{e}$ " $\sim \mathrm{N}\left(0, \sigma \mathrm{e}^{2}\right)$.

Estimates of fixed effects were obtained from the equation above and were subtracted from the original phenotype $y$ to get the adjusted phenotype $\left(y^{\prime}\right)$. The adjusted phenotype still contained the additive random genetic effects and residual.

$$
y^{\prime}=y-X_{1} \beta_{1}+X_{2} \beta_{2}+\ldots X_{n} \beta_{n}
$$

After adjusting for fixed effects, the three datasets were combined to make a single dataset for each trait with the adjusted phenotypes. The adjusted phenotypes $\left(y^{\prime}\right)$ for each trait were then used in all subsequent analyses.

\subsection{Genome-Wide Association Studies}

Genome wide association studies (GWAS) were done for the combined dataset of each trait using SNP \& Variation Suite v8.x Golden Helix [31]. Adjusted phenotypes from the above equation were used in a single locus (SNP-by-SNP) GWAS. Variance components were estimated through REML for each trait, separately, in which the GRM of all animals from the combined datasets for each trait was used to estimate the heritabilities of the traits using SNP \& Variation Suite v8.x Golden Helix. As the data in the combined datasets originated from different original datasets, the original datasets themselves were considered a fixed effect in this analysis. The following linear mixed model was used to perform GWAS for each trait:

$$
y^{\prime}=D \beta+Z \mu+S \alpha+e
$$

where $D$ is an incidence matrix of fixed effects (datasets), $\beta$ is the estimate of fixed effects. $Z$ is as previously described. $S$ is an incidence matrix of genotypes (coded as 0,1 , or 2 copies of the minor allele) and $\alpha$ is the estimate of SNP effects.

\subsection{Genetic and Phenotypic Correlation of the Traits}

Adjusted phenotypes were used to estimate pairwise genetic correlations amongst the three traits using SNP \& Variation Suite v8.x Golden Helix [31]. The analysis estimated variance components of the traits using the genomic relationship matrix through REML. The following equation was used to compute genetic correlations in trait pairs:

$$
r G=\frac{C(G 12)}{\sqrt{V(G 1) V(G 2)}}
$$


where $r G$ is the genetic correlation between two traits, $C(G 12)$ is the genetic covariance of the two traits, $V(G 1)$ and $V(G 2)$ are the genetic variances of the two traits.

The phenotypic correlation between the traits was calculated using the following equation [34]:

$$
r P=\frac{\sigma u x y+\sigma e x y}{\sqrt{\left(\sigma^{2} \mathrm{ux}+\sigma^{2} \mathrm{ex}\right) \times\left(\sigma^{2} \mathrm{uy}+\sigma^{2} \mathrm{ey}\right)}}
$$

where $r P$ is phenotypic correlation between two traits. $\sigma \mathrm{u}_{\mathrm{xy}}$ and $\sigma \mathrm{e}_{\mathrm{xy}}$ are genetic and residual covariances between two traits $x$ and $y$, respectively. $\sigma^{2} u_{x}$ and $\sigma^{2} u_{y}$ are genetic variances and $\sigma^{2} e_{x}$ and $\sigma^{2} e_{y}$ are the residual variances of traits $\mathrm{x}$ and $\mathrm{y}$.

\subsection{Multi-Trait Meta-Analysis}

Multi-trait meta-analysis was performed across three traits, using SNP \& Variation Suite v8.x Golden Helix [31]. Meta-analysis used SNP effects ( $\beta$ ) and their standard error (SE) from the three traits to construct $\chi^{2}$ distribution of the traits with following equation [35]:

$$
\text { Multi-trait } x^{2}=t^{\prime}{ }_{i} V^{-1} t_{i}
$$

where $t_{i}$ is a $3 \times 1$ vector of the $i$ th SNP effects divided by their respective standard errors, $t_{I}^{\prime}$ is the transpose vector of $t_{i}$, and $V^{-1}$ is an inverse of the $3 \times 3$ correlation matrix of the correlations between the $t$-values. Expected false discovery rate (FDR) for SNPs associations was computed as $f=\alpha \mathrm{m} / \mathrm{s}$, where $m$ is the total number of tests, $\alpha$ is threshold of significance, and $s$ is the number of significant tests with a $p$-value $<\alpha$. To determine the value of $\alpha$, resulting in FDR lower than 5\%, the procedure described by Benjamini [36] was applied. Here, $s$ was defined as the rank position " $i$ " with the largest $p$-value satisfying $P i \leq f i / m$ for $f=0.05[37]$.

\subsection{SNP Informed Positional Candidate Gene List}

Keeping in mind the extent of linkage disequilibrium (LD) in cattle [38], a list of genes within a $0.5 \mathrm{Mb}$ window of significant SNPs $\left(p\right.$-value $<9.0 \times 10^{-6}$, FDR $\left.<0.0001\right)$ was prepared. For this purpose, we used SNP and gene positions from the new reference genome reference genome (ARS_UCD1.2, GenBank assembly accession GCA_002263795.2) and ENSEMBL resources [39]. This gene list was termed "positional candidate gene list".

\subsection{Functional Pathway Analysis}

We used the positional candidate gene list from GWAS as the target gene list to perform gene ontology and pathway analysis using DAVID [40]. DAVID first classifies the genes present in the target gene list into their respective ontologies and biological pathways. Over-representation of a set of genes from the target gene list in specific pathways is then determined as a pathway enrichment score ( $p$-value), in comparison with a background gene list $[40,41]$. We used two background gene lists for this purpose: (1) default background list of Bos taurus in DAVID, which contains all annotated genes in the cattle genome; and (2) a trained background gene list. The trained background gene list consisted of genes annotated to known fertility pathways (taken from the KEGG PATHWAY database) and genes searched using "Guildify" software [42] with keywords related to fertility and puberty. The keywords were puberty, GNRH, luteinizing, follicle, ovary, hypothalamus, pituitary, calcium, estrogen, oocyte, meiosis, and progesterone.

\subsection{Using Information from Transcriptomics and Proteomics Studies Related to Cattle Puberty}

Lists of differentially expressed genes and proteins that emerged from the comparison of transcriptomics and proteomics data of hypothalamus, pituitary and ovaries of pre- and post-pubertal Brahman heifers were available from previous work of our group [43-45]. In these previous studies, the comparative transcriptomics and proteomics of the hypothalamus, pituitary and ovarian tissues of pre- vs. post-pubertal cattle was done by RNA sequencing and tandem mass spectrometry (MS/MS), respectively. Both transcriptomics 
and proteomics approaches identified candidate genes involved in the onset of puberty in Brahman cattle. The genomics approaches in current study also aimed to address early reproductive traits, involving the phenomenon of puberty. We combined the significant differentially expressed genes lists from these previous transcriptomics and proteomics experiments and named the new gene list as "transcriptomics-proteomics gene list". This gene list was compared with the positional candidate gene list of the current study to identify common genes between similar but two independent experimental approaches. The resultant common gene list was named "common multi-omics gene list".

\subsection{Transcription Factor Analysis}

The fertility-related trained background gene list, which we prepared for the gene ontology and pathway analysis above, was also used to identify top transcription factors for the genes involved in fertility-related pathways using PASTAA [46]. Briefly, the genes of fertility related trained background gene list were searched in ENSEMBL for human homologues. The human homologues were then used as input to the PASTAA software and affinity scores of transcription factors were determined for the input list of genes. The transcription factors with the highest affinity scores were termed as top transcription factors. The top transcription factors were cross-checked with the positional candidate gene list of this study to verify if they were also in proximity with significant SNP from this study.

\section{Results}

The accuracy of imputation, in terms of allelic $\mathrm{R}^{2}$, for CRC, Kamilaroi and NT DITT cows' datasets was $0.95,0.93$ and 0.92 , respectively. Linear mixed model analysis of three traits resulted in low-to-moderate heritabilities, 0.11 for FCS, 0.17 for PREG1, and 0.28 for REB. Genetic and phenotypic correlations between the three traits were positive and high (Table 2).

Table 2. Heritabilities, genetic and phenotypic correlations for reproductive traits in Brahman cows.

\begin{tabular}{cccc}
\hline Traits & PREG1 & FCS & REB \\
\hline PREG1 & $0.17(0.03)$ & $0.839(0.06)$ & $0.799(0.07)$ \\
\hline FCS & $0.86(0.01)$ & $0.11(0.03)$ & $0.756(0.1)$ \\
\hline REB & $0.73(0.02)$ & $0.65(0.02)$ & $0.28(0.05)$ \\
\hline
\end{tabular}

Diagonal from top-left to bottom-right represents heritabilities of the traits. Above the diagonal are genetic correlations of the traits. Below the diagonal are phenotypic correlations of the traits. Standard errors are in parentheses. PREG1: Pregnancy outcome after first mating chance. FCS: first conception score. REB: rebreeding score.

The individual GWA studies showed a few moderately significant SNPs for each trait. In total, 59 suggestively associated SNPs $\left(p\right.$-value $\left.<9.9 \times 10^{-5}\right)$ were present across different chromosomes for PREG1 (Figure 1). For PREG1, the SNP with highest significance $\left(p\right.$-value $2.0 \times 10^{-7}$ ) was on chromosome 8 . A cluster of SNPs associated with PREG1 was present on chromosome 21 with the peak SNP having a $p$-value of $1.1 \times 10^{-6}$. GWAS results for FCS comprised of 51 SNPs above the threshold $\left(p\right.$-value $<9.9 \times 10^{-5}$ ) for suggestive association (Figure 1). The SNP with the highest significance for FCS ( $p$-value $\left.2.4 \times 10^{-7}\right)$ was on chromosome 1 . Two more SNPs in the same chromosome 1 region were observed, with $p$-values $2.9 \times 10^{-7}$ and $3.3 \times 10^{-7}$. GWAS for REB resulted in 42 suggestive SNPs $\left(p\right.$-value $\left.<9.9 \times 10^{-5}\right)$ across different chromosomes, and the top five SNPs were on chromosome 7, 11 and 21 (Figure 1). 


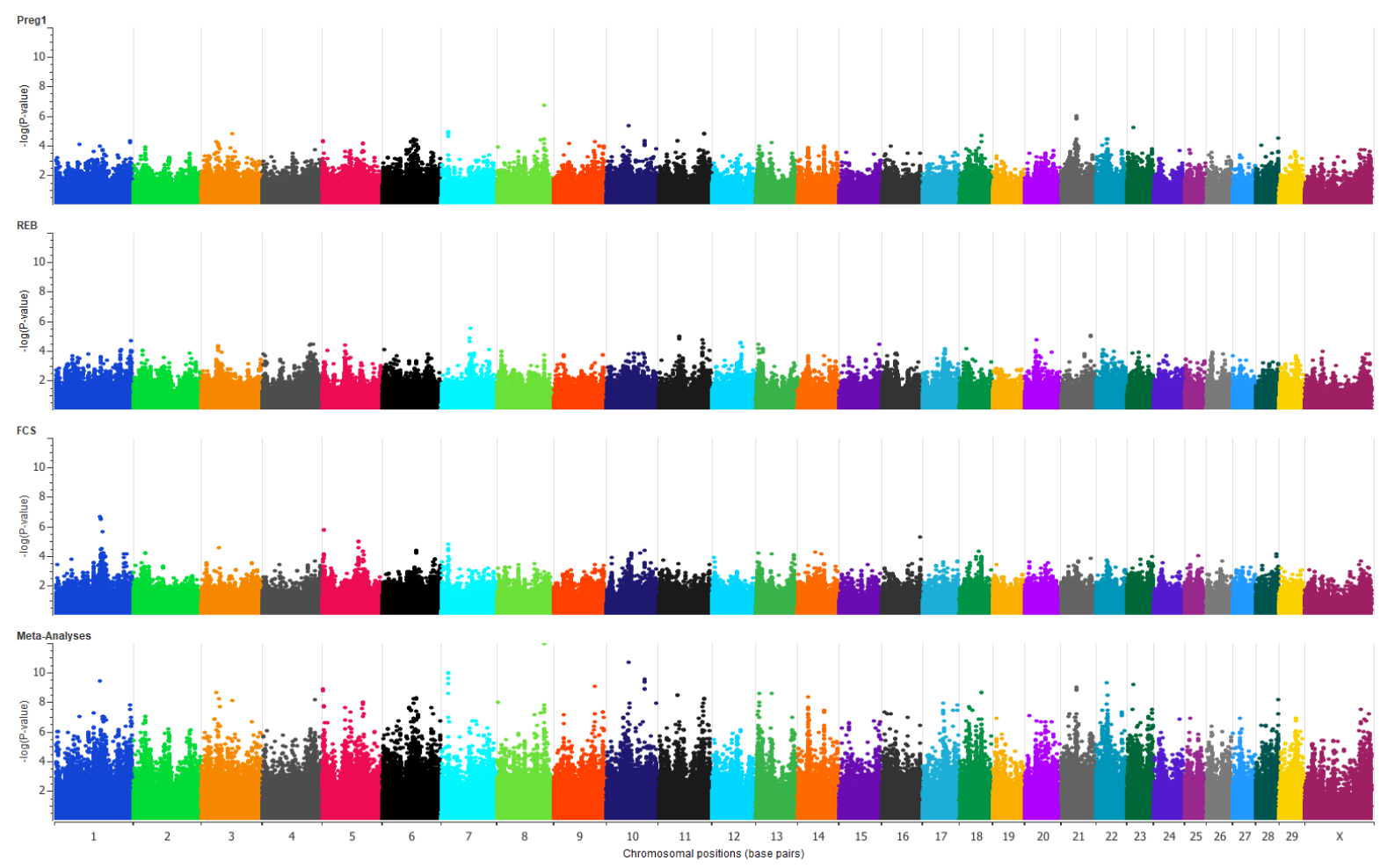

Figure 1. Genome-wide association studies of three early reproductive traits and their meta-analysis. Polymorphism association plots for pregnancy after first mating opportunity (PREG1), rebreeding score (REB), first conception score (FCS), and multi-trait meta-analysis are represented from top to bottom, respectively. In each plot, the $x$-axis has the chromosomal positions and the $y$-axis is the $-\log (p$-value) of each SNP association.

Multi-trait meta-analysis of the three traits resulted in 1359 significant SNPs with a $p$-value $<9.9 \times 10^{-6}$ at FDR $<0.0001$ (Figure 1) (Table S2). The top five chromosomes had $36.57 \%$ of all significant SNPs; they were chromosomes 1 (114 SNPs), 22 (111 SNPs), 6 (106 SNPs), 11 (87 SNPs) and 5 (79 SNPs). These SNPs association results corroborate the polygenic nature of reproductive traits.

We mined the $0.5 \mathrm{Mb}$ around all significant SNPs ( $p$-value $<9.9 \times 10^{-6}$, FDR $<0.0001$ ) and listed 2560 positional candidate genes. The most significant SNP out of the multi-trait meta-analyses was ARS-BFGL-NGS-111964 ( $p$-value $1.15 \times 10^{-12}$ ) mapped to chromosome 8. The genomic region of $0.5 \mathrm{Mb}$ around this top SNP has six genes, SLC44A1, FSD1L, FKTN, TAL2, TMEM38B and U6. Chromosomes 3, 5, 7, 9, 10, 21, 22, 23, and 28 also harbored positional candidate genes $(0.5 \mathrm{MB})$ near peak SNPs. The genes near peak SNPs were ESR2, ITPR1, GNG2, RGS9BP, ANKRD27, TDRD12, GRM1, MTHFD1, PTGDR and NTNG1. Among all positional candidate genes, some are well known as fertility-related genes. We listed selected candidate genes, based on current knowledge of reproductive biology (Table 3). For the full list of positional candidate genes, see Table S3.

Gene ontology and pathway analyses of the positional candidate gene list resulted in classification of the genes into 167 KEGG biological pathways (number of genes in pathway $\geq 6$ ) (Table S4). However, none of the classified pathways were significantly enriched for functional over-representation when the default Bos taurus background gene list was used in the enrichment analysis in DAVID. Similarly, no biological process gene ontology terms were enriched for the target candidate gene list, when compared to the default background. However, using DAVID, we did classify the genes in the positional candidate list into several biological process, including Transcription-DNA template, Translation, Cell proliferation, and spermatogenesis (Table S4). 
Table 3. Genes known for their reproductive biology function, in the vicinity of significant SNPs.

\begin{tabular}{|c|c|c|c|c|c|c|}
\hline SNP & Gene & BTA & $\begin{array}{l}\text { Location } \\
\text { of SNP }\end{array}$ & $p$-Value & Function & Overall SNP Effect \\
\hline BovineHD1100009366 & LHCGR & 11 & 31339285 & $7.8 \times 10^{-6}$ & Steroid Synthesis & 0.057 \\
\hline BovineHD1100009366 & FSHR & 11 & 31339285 & $7.8 \times 10^{-6}$ & Steroid Synthesis & 0.057 \\
\hline BovineHD4100003128 & $L E P$ & 4 & 92253894 & $4.0 \times 10^{-6}$ & GnRH Secretion & 0.053 \\
\hline BovineHD1400007251 & MOS & 14 & 23304037 & $1.8 \times 10^{-7}$ & Oocyte Maturation & 0.059 \\
\hline BovineHD2200014848 & $C D C 25 A$ & 22 & 51689566 & $4.6 \times 10^{-6}$ & Oocyte Maturation & -0.050 \\
\hline BovineHD2200003516 & $A V C R 2 B$ & 22 & 11918372 & $4.6 \times 10^{-7}$ & TGF- $\beta$ Signaling & -0.056 \\
\hline BovineHD2200000211 & EGFR & 22 & 878627 & $8.0 \times 10^{-6}$ & GnRH Signaling & -0.052 \\
\hline BovineHD2500007459 & MAPK3 & 25 & 26160282 & $3.4 \times 10^{-6}$ & GnRH Signaling & 0.060 \\
\hline BovineHD1000021917 & ESR2 & 10 & 76586616 & $3.0 \times 10^{-10}$ & Estrogen Signaling & -0.114 \\
\hline BovineHD0900023775 & GRM1 & 9 & 83806867 & $9.5 \times 10^{-10}$ & Glutamate Signaling & -0.066 \\
\hline BovineHD1700011908 & GRIA2 & 17 & 41973761 & $3.0 \times 10^{-6}$ & Glutamate Synapse & 0.098 \\
\hline BovineHD2500002242 & GRIN2A & 25 & 8381736 & $4.2 \times 10^{-6}$ & Glutamate Synapse & 0.057 \\
\hline BovineHD2200005404 & GRM7 & 22 & 18702200 & $4.4 \times 10^{-6}$ & Glutamate Synapse & 0.070 \\
\hline BovineHD0600018549 & GABRA4 & 6 & 65504186 & $3.1 \times 10^{-6}$ & GABAergic Synapse & -0.050 \\
\hline BovineHD0200007364 & GAD1 & 2 & 25614206 & $7.9 \times 10^{-6}$ & GABAergic Synapse & -0.053 \\
\hline BovineHD0600018549 & GABRB1 & 6 & 65504186 & $3.1 \times 10^{-6}$ & GABAergic Synapse & -0.050 \\
\hline BovineHD0600018311 & GABRA2 & 6 & 64738586 & $3.3 \times 10^{-6}$ & GABAergic Synapse & -0.048 \\
\hline BovineHD0600018311 & GABRG1 & 6 & 64738586 & $3.3 \times 10^{-6}$ & GABAergic Synapse & -0.048 \\
\hline BovineHD1300000677 & PLCB4 & 13 & 2565300 & $9.7 \times 10^{-6}$ & Calcium Signaling & 0.047 \\
\hline BovineHD2200006328 & ITPR1 & 22 & 21699681 & $5.2 \times 10^{-10}$ & Calcium Signaling & -0.092 \\
\hline BovineHD0400018696 & CREB5 & 4 & 67587933 & $3.8 \times 10^{-6}$ & cAMP Signaling & -0.082 \\
\hline BovineHD1800005855 & ADCY7 & 18 & 18675150 & $4.5 \times 10^{-7}$ & cAMP Signaling & 0.059 \\
\hline BovineHD0600018878 & CNGA1 & 6 & 66763069 & $7.2 \times 10^{-7}$ & cAMP Signaling & 0.062 \\
\hline BovineHD0700033604 & $P D E 4 A$ & 7 & 15081779 & $2.2 \times 10^{-7}$ & cAMP Signaling & 0.064 \\
\hline BovineHD0300002075 & HSD17B7 & 3 & 6617455 & $1.3 \times 10^{-6}$ & Steroid Synthesis & -0.052 \\
\hline BovineHD2100009894 & CYP11A & 21 & 34099081 & $4.2 \times 10^{-7}$ & Steroid Synthesis & -0.052 \\
\hline BovineHD1400007252 & PLAG1 & 14 & 23313248 & $1.8 \times 10^{-7}$ & $\begin{array}{c}\text { Transcription } \\
\text { Regulation }\end{array}$ & 0.059 \\
\hline BovineHD2300013198 & TFAP2A & 23 & 45590544 & $1.7 \times 10^{-6}$ & $\begin{array}{l}\text { Transcription } \\
\text { Regulation }\end{array}$ & 0.058 \\
\hline BovineHD1100029888 & TTF1 & 11 & 102587601 & $3.2 \times 10^{-6}$ & $\begin{array}{c}\text { Transcription } \\
\text { Regulation }\end{array}$ & 0.046 \\
\hline BovineHD2100008703 & CHRNA7 & 21 & 29677844 & $1.9 \times 10^{-7}$ & Cholinergic Synapse & -0.063 \\
\hline BovineHD2700004441 & MTNR1A & 27 & 16259785 & $1.1 \times 10^{-6}$ & Melatonin Receptor & -0.048 \\
\hline
\end{tabular}

When the positional candidate gene list was analyzed for gene ontology terms and pathways enrichment using the trained background gene list, 66 KEGG biological pathways were significantly enriched (Benjamini corrected $p$-value $<4.6 \times 10^{-2}$ ) (Table S4). Selected biological pathways, which are directly related to fertility, as per prior literature-based knowledge, are listed in Table 4 (they are a subset of Table S4).

Our functional annotation allowed grouping of position candidate genes according to their biological role. The MAPK signaling pathway, which includes kinases and regulates proteins in a variety of biological pathways, was represented by 32 genes in the positional candidate gene list. Out of these, nine were protein kinases, including MAPK3, MAP3K20, MAP3K19, MAPK14, MAPK13, MAPK8, MAPK6, MAP3K1 and MAP3K11, and were within $0.5 \mathrm{Mb}$ of significant SNPs on chromosomes 2, 10, 23, 25, 28, and 29. Two growth factors, bone morphogenic protein-5 (BMP5) on chromosome 23 and platelet-derived growth factor-C (PDGFC) on chromosome 17, were also near significant SNPs. Receptors of different growth factors, such as BMPR1B, PDGFRA, PDGFRB and EGFR and the receptor of the growth hormone $G H R$, were in the positional candidate gene list close to significant SNPs on chromosomes 6, 7, 20 and 22. The positional candidate gene list also included cytokines and cytokine receptors-IL26, IL7, IL19, IL20, IL24, IL16, IL27, IFNG, IL1R1, IL1RL2, IL1RL1, IL18R1 and IL19RAP - and two adipokines, LEP and APLN. Five genes including GABRG1, GABRA2, GABRA4 and GABRB1 belonged to GABAergic Synapse. 
Seven polymerase genes including POLR3B, POLN, POLE2, PRIMPOL, POLR3A, POLA1 and POLA2 were mapped within the $0.5 \mathrm{Mb}$ region of significant SNPs in this study. In total, 86 olfactory receptors were nearby significant SNPs and were included in our positional candidate gene list. Classification of positional candidate genes into biological pathways and functional groups allowed curation of integrated pathways and molecular mechanisms that may contribute to pubertal development and therefore impact on heifer fertility (Figures 2-4).

Table 4. Known reproductive pathways significantly enriched in the positional candidate gene list.

\begin{tabular}{|c|c|c|c|}
\hline Pathway & Gene Count & Gene Names & $\underset{p \text {-Value }}{\text { Adj. }}$ \\
\hline GnRH Signaling & 16 & $\begin{array}{c}\text { RAF1, SOS2, ADCY7, CAMK2A, CAMK2D, EGFR, ITPR1, ITPR2, } \\
\text { MAPK13, MAPK3, MAPK8, MAP3K1, PLA2G4D, PLA2G4E, } \\
\text { PLA2G4B, PLCB4 }\end{array}$ & $1.2 \times 10^{-3}$ \\
\hline $\begin{array}{l}\text { Progesterone Mediated } \\
\text { Oocyte Maturation }\end{array}$ & 13 & $\begin{array}{c}\text { BRAF, RAF1, ADCY7, CDC25A, HSP90AA1, HSP90AB1, } \\
\text { MAPK10, MAPK13, MAPK3, MAPK8, PIK3CB, SPDYC, MOS } \\
\text { FKBP5, RAF1, ADCY7, CREB3L2, ESR2, SOS2, GRM1, }\end{array}$ & $5.6 \times 10^{-3}$ \\
\hline Estrogen Signaling & 17 & $\begin{array}{c}\text { HSP90AA1, HSP90AB1, ITPR1, EGFR, ITPR2, MAPK3, OPRM1, } \\
\text { PIK3CB, PLCB4, AKT1 }\end{array}$ & $1.2 \times 10^{-3}$ \\
\hline Glutamatergic Synapse & 15 & $\begin{array}{l}\text { GNG2, ADCY7, GRIA2, GRIN2A, GRIK1, GRM7, GRM1, GLS2, } \\
\text { ITPR1, ITPR2, MAPK3, PLA2G4B, PLA2G4E, PLA2G4D, PLCB4 } \\
\text { BRAF, MRAS, LIMK2, RAF1, ARHGEF1, CHRM5, CYFIP2, }\end{array}$ & $7.0 \times 10^{-2}$ \\
\hline $\begin{array}{l}\text { Regulation of Actin } \\
\text { Cytoskeleton }\end{array}$ & 25 & $\begin{array}{c}\text { ENAH, FGFR3, ITGA4, ITGA8, ITGAL, ITGB2, MAPK3, MYLPF, } \\
\text { PAK2, PAK5, PIK3CB, PDGFC, PDGFRA, PDGFRB, MOS, VAV3, } \\
\text { ITG5, ITGB2 }\end{array}$ & $1.2 \times 10^{-3}$ \\
\hline Cholinergic Synapse & 17 & $\begin{array}{c}\text { AKT1, GNG2, ADCY7, CREB3L2, CAMK2A, CAMK2D, CHRM5, } \\
\text { CHRNA3, CHRNB4, CHRNA7, ITPR1, ITPR2, MAPK3, PIK3CB, } \\
\text { PLCB4, SLC5A7, KCNQ4 }\end{array}$ & $9.3 \times 10^{-4}$ \\
\hline cAMP Signaling & 24 & $\begin{array}{c}\text { AKT1, ATP2B3, BRAF, FXYD1, RAF1, RAPGEF4, ADCY7, } \\
\text { CREB3L2, CAMK2D, CNGA1, FSHR, GLP1R, GRIA2, GRIN2A, } \\
\text { MAPK3, MAPK8, NPR1, OXTR, PIK3CB, PDE4A, VAV3, ORAI1, } \\
\text { RELA, ADORA2A, CAMK2A. }\end{array}$ & $9.6 \times 10^{-4}$ \\
\hline Calcium Signaling & 26 & $\begin{array}{c}\text { ATP2B3, ATP2A1, ORAI1, ORAI3, ADCY7, AGTR1, CAMK2A, } \\
\text { CAMK2D, CHRM5, CHRNA7, EGFR, GRPR, GRIN2A, GRM1, } \\
\text { ITPR1, ITPR2, ITPKA, LHCGR, OXTR, PLCB4, PLCD1, PHKG2, } \\
\text { PDGFRA, PDGFRB, SLC25A4,VDAC2, ADORA2A }\end{array}$ & $3.6 \times 10^{-5}$ \\
\hline Focal Adhesion & 25 & $\begin{array}{c}\text { AKT1, BRAF, RAF1, SOS2, CAPN2, COL4A3, COL4A5, COL4A6, } \\
\text { ITGA4, ITGA8, ITGAB5, KDR, LAMC3, MAPK3, MAPK8, } \\
\text { MYLPF, PAK2, PAK5, PIK3CB, PDGFC, PDGFRA, CAV3, } \\
\text { PDGFRB, EGFR, VAV3, VWF, ZYX }\end{array}$ & $5.6 \times 10^{-4}$ \\
\hline PI3K-Akt Signaling & 40 & $\begin{array}{c}\text { AKT1, CD19, GNG2, RBL2, RELA, RAF1, SOS2, CREB3L2, } \\
\text { CASP9, CDC37, COL4A3, COL4A5, COL4A6, CSF1, CSF1R, } \\
\text { CDK6, CDKN1A, EGFR, FGF19, FGFR3, GHR, HSP90AA1, } \\
\text { HSP90AB1, ITGA4, ITGA8, ITGB5, IL7, KDR, LAMC3, LPAR1, } \\
\text { LPAR3, MAPK3, PIK3CB, PDGFC, PDGFRA, PDGFRB, PPP2R5E, } \\
\text { PPP2R2C, TSC1, VWF }\end{array}$ & $1.6 \times 10^{-3}$ \\
\hline Ovarian Steroidogenesis & 10 & $\begin{array}{c}\text { HSD17B7, ADCY7, ALOX5, CYP11A1, CYP1A1, FSHR, LHCGR, } \\
\text { PLA2G4B, PLA2G4D, PLA2G4E }\end{array}$ & $4.2 \times 10^{-3}$ \\
\hline
\end{tabular}

* Adj. $p$-value: $p$-value adjusted using FDR.

The functional roles of positional candidate genes identified in this study were ascertained from the previous literature, and known biological pathways. With the help of previous literature, the positional candidate genes related to glutamatergic, GABAergic, and cholinergic synapses, were integrated into molecular mechanisms that contribute to GnRH secretion (Figure 2), and therefore puberty. Further, positional candidate genes involved in calcium, cAMP, estrogen, MAPK, PIK3B, and adipocytokines signaling, were identified as part of the mechanisms that excite GnRH neurons, prior to GnRH secretion by the exocytosis machinery. In summary, functional annotation of the positional candi- 
date genes led to an integrated view of hypothalamic mechanisms that regulate in GnRH secretion (Figure 2).

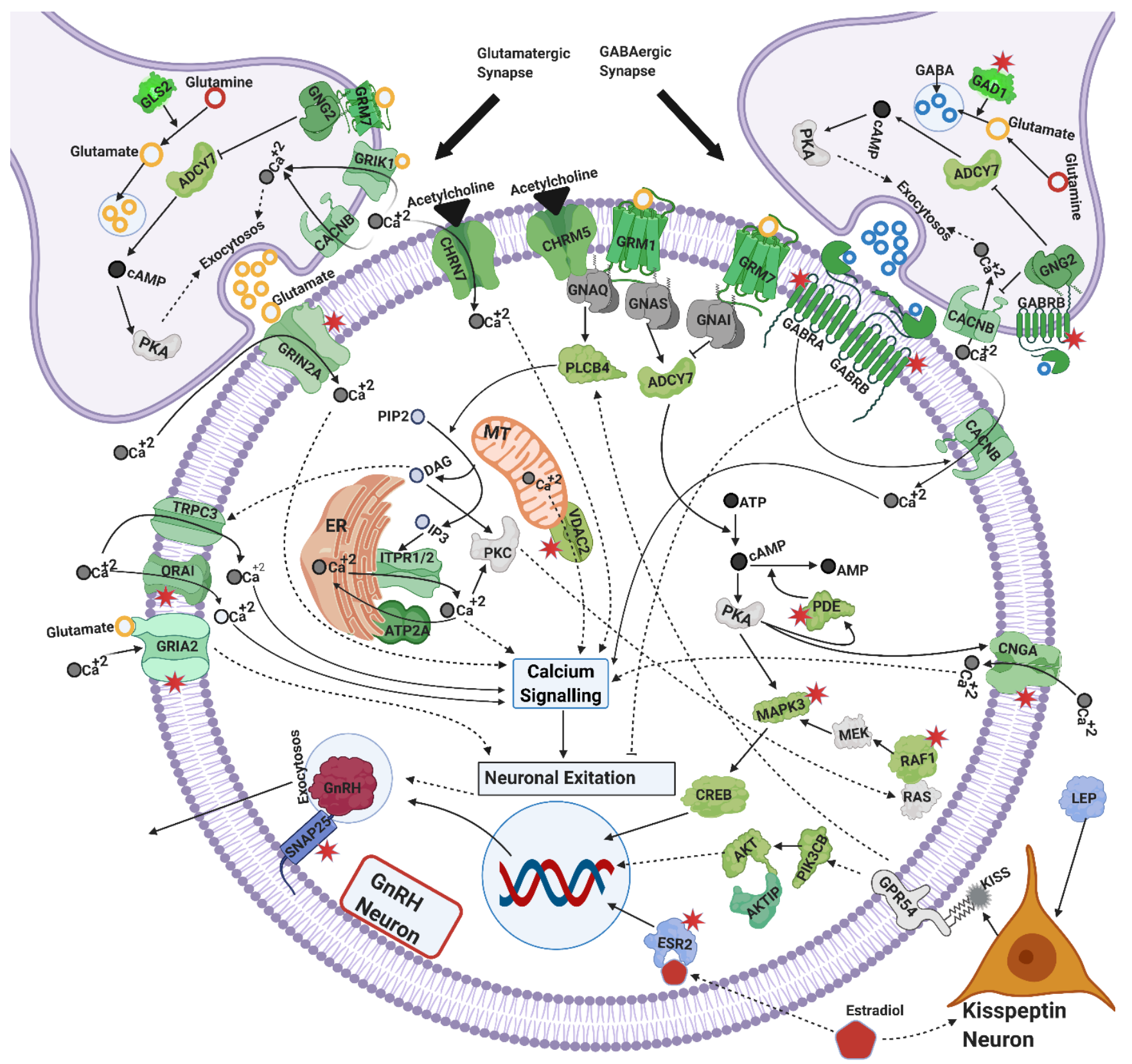

Figure 2. Mechanisms of GnRH secretion in the hypothalamus: insights from positional candidate genes identified in the meta-analyses of heifer fertility traits. Figure includes interaction of neurotransmitters from glutamatergic, GABAergic, cholinergic and Kisspeptin neurons with their respective receptors to excite GnRH neurons through calcium and cAMP signaling for GnRH secretion. Proteins in green represent the positional candidate genes, within $0.5 \mathrm{Mb}$ of significant SNPs, which are also known in these KEGG pathways. Blue proteins represent the positional candidate genes placed in these intricate mechanisms based on the literature (but are not known from KEGG pathways). Grey proteins were not represented in the positional candidate gene list, but are components of the proposed mechanism due to current literature [6,10,47-67] and KEGG pathways. Red stars identify proteins from this study in common with previous proteomics and transcriptomics analyses of pre- vs post-pubertal heifers. 


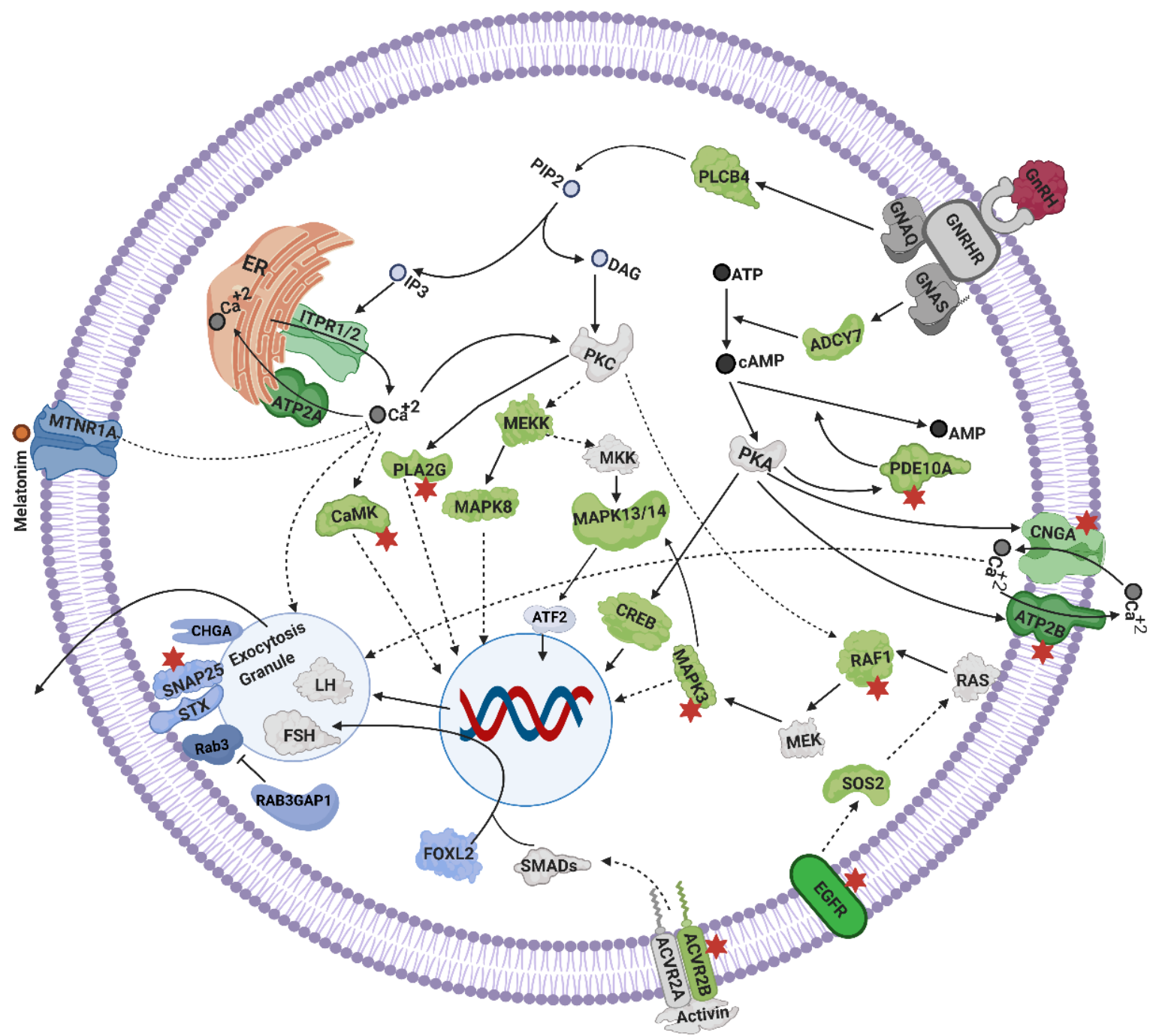

Figure 3. Mechanisms of gonadotrophins secretion in the pituitary gland: insights from positional candidate genes identified in the meta-analyses of heifer fertility traits. GnRH after binding to its receptor activates multiple signaling pathways including calcium, cAMP and growth factor signaling to express and secrete FSH and LH. Proteins in green represent positional candidate genes (within $0.5 \mathrm{Mb}$ of significant SNPs), which were also reported in respective KEGG pathways. Blue proteins represent positional candidate genes integrated here because of current literature cited (but are not known from KEGG pathways). Grey proteins indicate the genes which were not listed as positional candidates, but are components of the proposed mechanisms due to known pathways or current literature [14,67-77]. Red stars identify proteins from this study which are in common with previous proteomics and transcriptomics analyses of pre- vs post-pubertal heifers.

The functional annotation of positional candidate genes also led to insights about the signaling mechanisms in pituitary gland that lead to gonadotrophin synthesis and secretion. The positional candidate genes PLA2G, CaMK, MAPK3, RAF1, PDE10A, ATP2B, CNGA, EGFR, and ACVR2B could be seen as part of the complex mechanisms of pituitary signaling (Figure 3), and they were also reported in previous proteomics and transcriptomics studies related to heifer puberty. These and more positional candidate genes fit with GnRH, calcium, cAMP, activin, melatonin, and MAPK signaling mechanisms that are important for the synthesis and secretion of gonadotrophins from the pituitary gland (Figure 3). Together, functions of positional candidate genes and current knowledge of pathways formed an integrated view of the mechanisms that may influence FSH and LH secretion (Figure 3), important for female reproduction. 


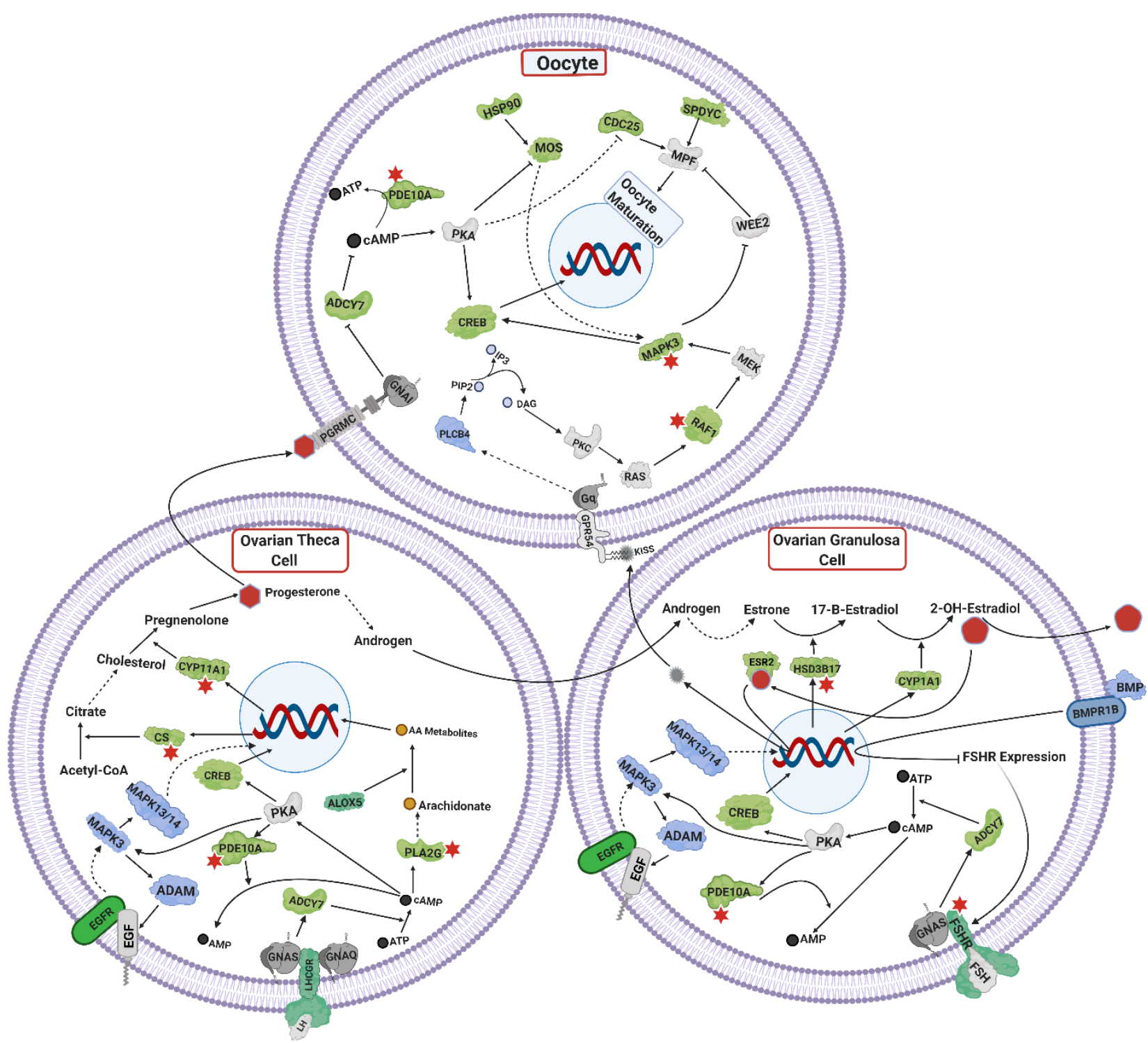

Figure 4. Mechanisms of steroid synthesis and oocyte maturation in ovarian cells: insights from positional candidate genes identified in the meta-analyses of heifer fertility traits. Receptors for LH and FSH in theca and granulosa cells initiate the signaling cascades for steroidogenesis, follicular growth and oocyte maturation. Proteins in green represent positional candidate genes (within $0.5 \mathrm{Mb}$ of significant SNPs) for which there is also evidence from KEGG pathways. Blue proteins represent positional candidate genes placed in the proposed mechanisms because of current literature (but are not identified in KEGG pathways). Gray proteins indicate the genes that were not positional candidates, but were included based on current literature [67,78-89]. Red stars mark genes were in common between this study and previous proteomics and transcriptomics analyses of pre- vs post-pubertal heifers.

Functional annotation of positional candidate genes led to propose an integrated mechanism of steroids synthesis and oocyte maturation, in ovarian tissue. Positional candidate genes coded for proteins involved in ovarian steroidogenesis, progesterone mediated oocyte maturation, cAMP signaling, PIK3B signaling and MAPK signaling (Figure 4). The integration of positional candidate genes across these known pathways led to the illustration of molecular mechanisms within theca and granulosa cells, as well as the oocyte, giving an overview of ovarian function (Figure 4).

Positional candidate genes were cross-checked with lists of differentially expressed genes and proteins from previous studies on heifer puberty and 392 genes in common were identified. Notably, fertility-related genes were among the 392 in genes common: CS, BRAF, GABRA2, GABR1B, GAD1, FSHR, CNGA3, PDE10A, SNAP25, ESR2, GRIA2, 
ORAI1, EGFR, CHRNA5, VDAC2, ACVR2B, ORAI3, CYP11A1, GRIN2A, ATP2B3, CAMK2A, $P L A 2 G, C A M K 2 D, H S D 17 B$ and MAPK3. Among these common genes BRAF, GABRA2, GABR1B, CNGA3, PDE10A, SNAP25, ESR2, GRIA2, ORAI1, VDAC2, ORAI3, GRIN2A and $M A P K 3$ are part of the mechanisms involved in GnRH secretion (Figure 2). Among these common genes, some were considered part of gonadotrophin secretion mechanisms in the pituitary gland (BRAF, CAMK2A, CAMK2D, SNPA25, ACVR2B, PDE10A, EGFR and $P L A 2 G$, see Figure 3), while others were annotated as part of the ovarian pathways (CS, FSHR, HSD17B, PDE10A, BRAF, MAPK3, and CYP11A1, see Figure 4).

The positional candidate gene list included 133 transcription factors, 40 transcription co-factors and 15 chromatin-remodeling factors. Three transcription factors, TAL2, ESR2 and ZBTB1, were nearby highly significant SNPs $\left(p\right.$-value $\left.<9 \times 10^{-9}\right)$. The positional candidate gene list included 48 transcription factors possessing zinc finger domains. PLAG1, a zinc finger-containing transcription factor, is located within $0.5 \mathrm{Mb}$ of BovineHD1400007251 $\left(p\right.$-value $\left.=1.7 \times 10^{-7}\right)$, and two more significant SNPs on chromosome 14. In addition, we used the trained background gene list to identify transcription factors that might be related to heifer fertility. The transcription factor AP2- $\alpha(T F A P 2 A)$ was the top regulator with the highest affinity score 14.38 ( $p$-value $\sim 0$ ) for the trained background gene list. TFAP2A is located on chromosome 23, in the $0.5 \mathrm{Mb}$ window of BovineHD2300013198, a peak SNP $\left(p\right.$-value $\left.=1.7 \times 10^{-6}\right)$. Two more transcription factors of this same class, TFAP2B and TFAP2D, were in the vicinity of BovineHD2300006011 $\left(p\right.$-value $\left.=7.6 \times 10^{-6}\right)$ on chromosome 23.

\section{Discussion}

Heritabilities of age at first calving and rebreeding score reported for Bos indicus cattle in Brazil are 0.10 and 0.22, respectively [90]. Heritability of PREG1 after fixed time artificial insemination is recorded as 0.18 in a different population of Brahman heifers [16]. We found heritabilities of REB and PREG1 as 0.28 and 0.17, respectively, which are similar to the estimates in cited studies. Although there were no other studies on FCS, this newly defined trait is based on early conception in the mating season and as such resembles age at first calving or a refinement of PREG1. Heritability of FCS was estimated as 0.11 in our study, which is similar to the heritability estimates of 0.10 for age at first calving in Brahman cattle in Brazil [90]. Three traits in this study were based on the similar records that confirmed pregnancy (or failure) after the first two mating seasons. Heifers can conceive in the first two mating seasons only after they have achieved puberty, marked as the first ovulation, which can be followed by the observation of the first corpus luteum [2]. Therefore, PREG1, FCS, and REB are all influenced by the same biological phenomenon: puberty. The same biological basis of the three traits confirmed high genetic correlations among these traits which was estimated in this study. In this study, after estimating heritabilities, we performed individual trait GWAS followed by meta-analysis.

Association studies, such as GWAS carried out on single traits that have low heritability expect SNP association with low-to-moderate significance, resulting in a high FDR [25]. Meta-analysis across traits may mitigate this problem and help to identify significant SNPs [23]. In the meta-analysis, we combined PREG1, FCS, and REB information that identified 1359 SNPs with a $p$-value lower than $9.0 \times 10^{-6}$ and FDR $<0.0001$, providing evidence for SNP associations that were not clear in the single-trait GWAS. Significant SNPs served as landmarks to propose positional candidate genes, which were subjected to pathway enrichment analyses and functional annotation. As a result, positional candidate genes were implicated in intricate mechanisms that influence puberty and fertility: pathways that trigger GnRH secretion in the Hypothalamus, mechanisms related to gonadotrophin secretion in the pituitary, and steroidogenesis as well as oocyte maturation in the ovaries.

Among positional candidate genes, 392 genes had been associated with heifer puberty before, in either transcriptomics or proteomics analyses of another set of Brahman cows. These genes identified in other "omics" studies add evidence to the role of these genes in the proposed mechanisms in this study. To facilitate the discussion, positional candidate 
genes were grouped into known pathways. Yet, first, we highlight genes of interest located in the vicinity of peak SNPs.

\subsection{Genes Located within $0.5 \mathrm{Mb}$ of Peak SNPS}

We considered every SNP with a $p$-value $<10 \times 10^{-9}$ as a peak SNP. The $0.5 \mathrm{Mb}$ genomic region around a peak SNP on chromosome 8 contains six genes SLC44A1, FSD1L, FKTN, TAL2 and TMEM38B. The same genomic region, but on chromosome 9 in humans, including the homologous genes FKTN, FSD1l, TAL2 and TMEM38B, is associated with age of female at sexual maturation [91]. Two more GWAS reported SLC44A1 and TMEM38B as candidate genes for age at first sex and pubertal growth in humans [92,93].

The peak SNP region on chromosome 18 harbored the genes RGS9BP, ANKRD27 and $T D R D 12$. Variants in vicinity to this region are associated with daughter pregnancy rate in Holstein cattle [94]. A peak SNP in chromosome 3 pointed to VAV3 as a candidate gene in this study. An SNP near this gene is associated with "interval from first to last insemination", a trait that contributes to the fertility index in Nordic Red cattle [95]. The gene $I D H 3 A$ was in the peak SNP region on chromosome 21. The protein coded by IDH3A was up regulated in the ovaries of post-pubertal heifers as compared to pre-pubertal heifers [96]. The gene PTGDR was within a peak SNP region in this study and had been reported as a candidate in a previous GWAS as associated with age at first calving in cattle [97]. In short, these candidate genes suggested by peak SNPs have supporting evidence from previous studies. Nonetheless, their role in heifer fertility requires further validation, because assigning genes to significant SNPs purely on genomic location is imperfect. For example, the peak SNP in chromosome 3 could point to VAV3 as discussed above, or it could suggest the candidate gene NTNG1 that is involved with axon guidance and can disturb glutamatergic and dopaminergic signaling [98]. The axon guidance pathway coordinates migration of neurons and their connectivity, which influences GnRH neurons and therefore puberty. More about the role GnRH and glutamatergic neurons in puberty is described in the following sections.

The gene ESR2 is another positional candidate, suggested by the peak SNP in chromosome 10, which seems obvious from a biological perspective. Estrogen receptors, like $E S R 2$, are crucial in the reproductive axis $[99,100]$. A mutation in ESR2 resulted in a lack of puberty and complete failure of the ovarian function in women [101]. In mice, a mutated ESR2 can cause infertility [102]. Still, one cannot jump to conclusions, because the same peak SNP could suggest another gene: MTHFD1. It is less obvious, but MTHFD1 is involved in DNA methylation, and its mutations can cause neuronal abnormalities [103] that may also affect puberty.

\subsection{Exocytosis and GnRH Secretion}

The hormone GnRH is considered the gatekeeper of puberty in cattle and other mammals. The secretion of $\mathrm{GnRH}$ is a complex phenomenon that requires coordinated molecular mechanisms in multiple neurons in the hypothalamus. The neuron secretion of GnRH and other neurotransmitters is dependent on the exocytosis machinery. Proteins such as synapsins, tropomysins, synaptosomal-associated proteins, syntexins, synaptogamins, and liprins are involved in the secretion of $\mathrm{GnRH}$, gonadotrophins and neurotransmitters from their secretory vesicles $[77,104,105]$. The positional candidate gene list included such proteins: SYN3, TPM1, SNAP25, STX2, STX4, STX11, STX19, STX1B, SYT11 and PPFIA2. Calcium and CAMP signaling coordinate with these proteins in the exocytosis of GnRH, gonadotrophins and neurotransmitters at large $[65,77,104,105]$. Neurotransmitters secreted from neighboring neurons interact with GnRH neurons to trigger GnRH secretion. Neurotransmitters such as kisspeptin, glutamate, GABA, acetylcholine and melatonin bind to their receptors and stimulate GnRH secretion through calcium and cAMP signaling [10-12,64,106-109]. These mechanisms that contribute to exocytosis in neurons and to GnRH secretion were compiled in Figure 2, where the implicated candidate genes are 
represented in green. The following discussion expands on all the mechanisms illustrated in Figures 2-4.

\subsubsection{Calcium Signaling}

Twenty-six positional candidate genes were part of the calcium signaling pathway in this study. To name a few, ITPR1, ITPR2, TRPC3, CACNB2, VDAC2, ORA11, ORA13 and PLCB4, contribute to maintain calcium $\left(\mathrm{Ca}^{++}\right)$levels in cells [110]. High $\mathrm{Ca}^{++}$levels are correlated with excitation and firing of $\mathrm{GnRH}$ neurons, which result in secretion of GnRH [111]. High $\mathrm{Ca}^{++}$levels in GnRH neurons are achieved through two mechanisms including, the voltage-dependent $\mathrm{Ca}^{++}$influx from extracellular resources and the secretion of $\mathrm{Ca}^{++}$from intracellular calcium [112]. The gene CACNB2 encodes the $\beta$ subunit of L-type calcium receptors. L-type calcium receptors mediate the effects of GABA and glutamate signaling to regulate calcium intake from extracellular resources into $\mathrm{GnRH}$ neurons [113]. Kisspeptin signaling, via GPR54 and PLCB4, regulates $\mathrm{Ca}^{++}$levels in GnRH neurons through TRPC3 channels from extracellular sources, and through ITPR1/2 from intracellular sources [47,111,114,115]. Additionally, TRPC channels coordinate with ORAI calcium channels to modulate $\mathrm{Ca}^{++}$levels in hypothalamic neurons $[116,117]$. The gene $V D A C 2$ also regulates calcium levels from intracellular sources [118]. In short, these positional candidate genes linked to calcium signaling might contribute to the studied phenotypes of heifer fertility because they fit with the mechanisms of GnRH secretion via calcium signaling.

\subsubsection{Cyclic AMP (cAMP) Signaling}

Cyclic AMP (cAMP) is an important secondary messenger in the regulation of GnRH secretion. The positional candidate gene list included 25 genes of the cAMP signaling pathway in this study. Among these, ADORA2A, ADCY7, CNGA1, CNGA3, and four phosphodiesterases (PDE4A, PDE6A, PDE10A and PDA11A) are linked to CAMP signaling. Provision of cAMP increases GnRH secretion in GT1-7 neurons [119]. Studies report that the cAMP regulated CNG channels cause depolarization of GTI-7 neurons by increased $\mathrm{Ca}^{++}$levels which results in GnRH secretion [64,120]. Phosphodiestrases hydrolyze cAMP and are implicated in decreasing GnRH secretion from GTI cells by decreasing cAMP levels [63,120]. ADORA2A is involved in $A D C Y 7$ activation for cAMP production [121]. In GnRH neurons, $A D O R A 2 A$ is differentially expressed in pro-estrous and meta-estrous of mice, playing a role in the estrous cycle [122]. The positional candidate genes related to cAMP signaling might impact on heifer fertility because these mechanisms contribute to $\mathrm{GnRH}$ and gonadotrophin secretion, which are key hormones for reproductive function.

\subsubsection{Glutamatergic and GABAergic Synapse}

Sixteen genes from the positional candidate gene list were linked to glutamatergic synapse. Among these genes, GNG2, GRIA2, GRIN2A, GRM1, GRM7, ITPR1, and ITPR2 operate by regulation of $\mathrm{Ca}^{++}$signaling in $\mathrm{GnRH}$ neurons [6]. In Iranian Holstein cattle, a polymorphism near GRIN2A is associated with age at first calving [123]. The glutamate neurotransmitter activates GRIA2 (AMPA) and GRIN2A (NMDA) receptors [6] which further regulate $\mathrm{Ca}^{++}$in $\mathrm{GnRH}$ neurons and cause secretion of $\mathrm{GnRH}$ [124]. Glutamate signaling through GRM7, GNG2 and ADCY7 regulate auto-inhibition of glutamate secretion in the pre-synaptic membrane [125]. In the post-synaptic membrane in GnRH neurons, GRM1 is involved in GnRH secretion through cAMP signaling [126,127]. In short, these genes involved with glutamatergic synapses excite GnRH neurons.

While glutamatergic synapses are excitatory, GABAergic synapses result in inhibitory effects on GnRH neurons [108]. Four GABAergic receptors (GABRA4, GABRA2, GABRB1 and $G A B R G 1$ ) were identified in positional candidate gene list. Signaling of GABA through GABRA receptors coordinates with $N M D A$ and $A M P A$ receptors to activate $\mathrm{L}_{\text {-type }} \mathrm{Ca}^{++}$ channels $(C A C N B 2$,$) to elevate \mathrm{Ca}^{++}$levels for depolarization that results in $\mathrm{GnRH}$ secretion [112]. The same study describes the inhibitory effects of the receptor GABRB on 
excitation of GnRH neurons [113]. Importantly, during puberty the effect of GABA signaling through its GABRA and GABRB receptors inhibits secretion of GnRH [128]. The coordinated glutamatergic and GABAergic pathways impact on pubertal development as they affect GnRH signaling. After puberty, these mechanisms (and by extension the identified genes) continue to be important for reproductive function as they orchestrate hypothalamic activity.

\subsubsection{Cholinergic Synapse}

Seventeen genes from the positional candidate gene list are known for their role in cholinergic synapse. Out of these, five were nicotinic acetylcholine receptors (CHRNA3, CHRNA5, CHRNA7, CHRNA9 and CHRNB4). Nicotine and acetylcholine through these receptors, especially CHRNA7, activate GT1-7 hypothalamic neurons and cause secretion of GnRH by elevating $\mathrm{Ca}^{++}$levels [10]. CHRNA7 is also believed to act as a calcium permeable channel which allows an influx of extracellular calcium into GnRH neurons stimulating hormonal secretion [10]. The muscarinic cholinergic receptor CHRM5 couples with $\alpha$ subunit of $\mathrm{G}_{\mathrm{q} / 11}$ protein and activates phospholipase- $\mathrm{C}$ to elevate $\mathrm{Ca}^{++}$levels for GnRH secretion [61]. Candidate genes linked to cholinergic synapse were integrated in the mechanisms that contribute to GnRH secretion (Figure 2), and therefore could be related to female reproduction.

\subsubsection{Melatonin Signaling}

A melatonin receptor MTNR1A was identified in the positional candidate gene list. Melatonin may act as a regulator of the estrous cycle in seasonal breeders [129,130]. Melatonin, through MTNR1A also inhibits calcium and cAMP levels, which might result in suppression of LH release from the pituitary gland (Figure 3). Melatonin signaling might influence the timing of puberty in seasonal breeders [76] and tropical heifers.

\subsubsection{Estrogen Signaling}

Estrogen signaling is important at all levels of the reproductive axis, in the hypothalamus, the pituitary gland and the ovaries. The genes ESR2, PIK3CB, AKT1, ITPR1, ITPR2, $C R E B 3 L 2$ and MAPK3 are members of estrogen signaling pathways and were identified as positional candidates in this study. These genes are involved in estrogen signaling that mediates GnRH secretion [131,132]. In GnRH neurons, ESR2 is expressed where it imparts rapid gene regulatory actions by phosphorylating CREB [133]. In GT-17 (GnRH producing) neurons ESR2 in the presence of estradiol increases cAMP production, activates calcium signaling, and causes GnRH secretion in a dose-dependent manner [134]. Estrogen signaling also works through kisspeptin neurons and regulates secretion of GnRH in hypothalamus [135]. The kisspeptin neurons in the anteroventral periventicular (AVPV) nucleus of the hypothalamus are believed to mediate positive feedback of estrogen signaling [136]. Kisspeptin neurons in the AVPV nucleus of the hypothalamus express high levels of estrogen receptor ESR2 [137]. It is not clear yet, but ESR2 along with ESR1 is implicated in regulation of GnRH through KISS signaling from AVPV nucleus of hypothalamus [138]. Leptin is implicated with the onset of puberty and related disorders in human females [139]. Leptin is implicated with the onset of puberty and related disorders in human females [139]. Leptin also directly or indirectly regulates GnRH secretion through Kisspeptin neurons [140-143]. It is not difficult to propose that estrogen signaling genes might impact heifer fertility and therefore could be proposed as both positional and functional candidate genes.

\subsection{Mechanisms Linked to Gonadotrophins Secretion by the Pituitary}

GnRH via its receptor stimulates the pituitary gland to secrete LH and FSH which then control ovarian function in an endocrine manner. Calcium and cAMP signaling work in synergy for the exocytosis of LH from pituitary cells [13]. The genes CREB5, PLCB, PLA2 (subunits G3, G7, G6, G1B, G4B, G4E, G4D) EGFR, SOS2, BRAF, RAF1, MRAS, 
MAPK3 (ERK), MAPK8 (JNK), MAP3K1 (MEKK), MAPK13/14 (p38MAPK), and ACVR2B were among positional candidates and were annotated as part of GnRH signaling cascades in the pituitary (Figure 3). This set of genes mediates the secretion of LH and FSH through PKC and EGFR signaling, involving MEKK, ERK and JNK signaling cascades [70,74]. Cyclic AMP also plays its role in the pituitary circuits through PKA, MAPK and CREB signaling [70]. EGFR through RAS, MAPK and p38MAPK signaling activates ATF2 transcription factor, which along with c-Jun and $A l K 1$, contributes to the transcription of $\alpha$ and $\beta$ subunits of gonadotrophin genes [70]. Through ERK signaling, focal adhesion and actin cytoskeleton remodeling are involved in the expression of $\mathrm{LH} \beta$ [14]. Among positional candidates, 27 genes were part of the focal adhesion pathway while 25 were linked to actin cytoskeleton remodeling in this study. Activin receptor $A C V R 2 B$ is known for its role in regulation of $F S H \beta$ transcription in gonadotrophs [75].

The positional candidate genes $C A M K 1 D, C A M K 2 D, C A M K 2 A$ and ATP2B3 are involved in calcium signaling mechanisms, which act on the pituitary for secretion of gonadotrophins. The gene CAMK through ITPR1 and ITPR2 mobilize $\mathrm{Ca}^{++}$stores and facilitate the expression and secretion of LH and FSH [14,71,72,144]. Elevated $\mathrm{Ca}^{++}$levels initiate rapid exocytosis of vesicles of gonadotrophins (LH and FSH) from pituitary cells [145]. Meanwhile, the role ATP2B3 is clearance of $\mathrm{Ca}^{++}$from pituitary cells afterwards [73].

Finally, some positional candidate genes could be linked to FSH and LH exocytosis. Five Syntaxins, CHAG, SNAP25 and RAB3GAP1 could be associated with exocytosis of gonadotrophins. Before exocytosis, FSH appears in granules associated with chromograninA (CHGA) [14]. The FSH and LH granules go through exocytosis with the help of exocytosis machinery including SNAP25/SNARE/Rab3 and syntaxins [14,77]. Active Rab3 is part of the exocytosis machinery and it is converted to the inactive form by an enzyme coded by RAB3GAP1 [146].

\subsection{Ovarian Steroidogenesis, and TGF Signaling}

The positional candidate genes FSHR, LHCGR, CYP11A1, CYP1A1, HSD17B, CREB and $C S$ are annotated to the ovarian steroidogenesis mechanisms (Figure 4). These genes are implicated in estrogen and progesterone synthesis from theca and granulosa cells of ovaries through FSHR and LHCGR signaling [78]. The cascade of FSHR/LHCGR and $P K A$, activates $C R E B$ which acts as a transcription factor for synthesis of steroid hormones in ovarian cells [147-149]. In Holstein cattle, an SNP near FSHR was associated with heifer conception rate, while another SNP linked to LHCGR gene is associated with the productive life of cows [150]. In Chinese Holstein cows, an SNP in the $5^{\prime}$ UTR region of FSHR is associated with superovulation [151]. The gene CS converts acetyl-CoA to citrate [152] which contributes to steroid synthesis downstream [96]. Steroidogenic genes CYP11A and HSD17B catalyze reactions of conversion of cholesterol to pregnanolone and estradiol-1 to estradiol-2, respectively [78].

The positional candidate genes BMP5, BMP8A, BMPR1B, GDF2, and GDF10 are part of TGF- $\beta$ superfamily. Bone morphogenic proteins (BMPs) and growth differentiation factors (GDFs) are implicated in ovarian steroidogenesis [78]. Bone morphogenic proteins (BMPs) and their receptors, are important regulators of follicular growth and androgen production in granulosa and theca cells $[153,154]$. Through their receptor BMPR1B, BMPs negatively impact the effect of FSH on ovarian cells by reducing the expression of its receptor FSHR [155]. Mutation in BMPR1B in sheep is associated with increased ovulation rate [156].

Multiple interleukins were identified as part of the positional candidate gene list in this study. Cytokines do interfere with steroidogenesis in a systemic manner [157]. Interleukin receptor IL1R1 was among the mapped genes in this study. The $I L-1$ through its receptor IL1R1, is involved in proliferation of theca and granulosa cells, and regulates steroidogenesis in mammals [78,158]. 


\subsection{Oocyte Maturation}

Oocyte maturation is crucial to cattle fertility [159]. Incompetent oocytes are a major reason for reduced fertility [160]. A complex interplay happens between steroids of theca cells, granulosa cells, and the oocyte for its maturation to occur. Positional candidate genes such as MAPK3, ADAMs, EGFR, MAPK13/14, PDE10A, CDC25A, ADCY7, SPEDY, $M A P K 8, E S R 2, P L C B, M O S, K I T$ and PABPC were all integrated in the oocyte maturation mechanisms (Figure 3). LH signaling activates MAPK3 signaling which induces metalloproteinases (ADAMs) in granulosa cells. Epidermal growth factor (EGF) cleaved by $A D A M$ activates its receptor EGFR. The EGFR in turn through RAS, MAPK3 pathway activates MAPK13/14 [161,162] which further activates transcription factors involved in oocyte maturation in pigs $[163,164]$. The EGF through EGFR also regulates synthesis of progesterone from theca cells and estrogen in granulosa cells. The progesterone through its membrane receptors is involved in oocyte maturation in mammals [165]. ADCY7, SPDYC and MAPK8, are also implicated in progesterone-mediated oocyte maturation $[85,166,167]$. Till now, the exact mechanisms are unknown, but somehow LH, EGFR, KISSR and progesterone signaling coordinate and play a vital role in mammalian oocyte maturation [168-171].

The gene PDE10A is expressed in granulosa cells and oocytes [172]. Increased cAMP levels activate PDE10A which after activation hydrolyses cAMP and cGMP to decrease their levels [173]. The decreased level of cAMP inactivates PKA and as a result CDC25A is activated. Activated $C D C 25$ activates the meiosis promoting factor (MPF) which causes oocyte maturation [174].

Another recently reported mechanism of oocyte maturation involves estrogen and kisspeptin signaling in ovaries. The ESR2 receptor in granulosa cells, after receiving estradiol, promotes KISS transcription. Paracrine action of KISS from granulosa cells activates KISSR in the oocyte, which further regulates oocyte maturation through PLCB, $D A G, P K C, R A S$ and MAPK3 in a signaling cascade, in rats [171]. This same study in rats, observed the upregulation of MOS, CDC25A, KIT and PABPC in oocytes after treatment with KISS agonist. These genes are also positional candidate genes in our meta-analysis. The gene MOS is one of the initially translated maternal mRNAs in oocyte, which further stimulates the oocyte maturation process [175]. The genes KIT and PABPC improve oocyte maturation by overcoming inhibitory effects of natriuretic peptide C (NPPC) signaling, and improving the stability of mRNAs for translation, respectively $[176,177]$.

\subsection{Olfactory Signaling}

We identified 86 genes from the positional candidate gene list as olfactory receptors. Olfactory receptors are expressed in olfactory receptor neurons and are involved in smell signal transduction. Pheromones present in bull urine contribute to onset of puberty in beef heifers [178]. Similarly, estrous pheromones can help bulls to detect pubertal heifers for mating [179]. Mating behavior is dependent on the olfactory receptors on vomeronasal olfactory neurons (VNO) and the main olfactory epithelium (MOE). Olfactory receptors transmit the signals of pheromones through VNO and MOE. These olfactory apparatuses extend their neuronal projections near the medial preoptic area (MPOA) region of hypothalamus where GnRH neurons reside [180]. Thus, chemo signaling for mating behavior is coordinated through GnRH neurons. Chemical disruption of VNO and MOE olfactory apparatuses impairs mating behavior and reduces MAKP phosphorylation in GnRH neurons [180]. Olfactory receptors were associated with reproductive traits herein and previously, in Nellore cattle [181,182].

\subsection{Transcription Factors}

The positional candidate gene list included three genes of the TFAP2 transcription factor family TFAP2A, TFAP2B, TFAP2D and 36 zinc finger transcription factors, one of which is PLAG1. Analysis of the fertility related trained background gene list in this study resulted in the identification of TFAP $2 A$ as a top regulator of reproduction-related genes. The family of TFAP2, especially TFAP2A and TFAP2B, are key regulators of gene expression 
in the bovine placenta and contribute to gestation progression [183]. TFAP2 is continuously required to produce LHRH in the forebrain of developing mice [184]. The PLAG1 gene has been associated with reproductive precocity in cattle in multiple studies [24,185].

Other transcription factors identified in the positional candidate gene list were FOXL2I, TTF1, POU5F1, NFAT5, PHTF1 and HDAC4. The FOXL2I is important for female reproduction in endometrium, ovarian and hypothalamic-pituitary tissues [186]. Transcription factor TTF1 binds to the promoter sequence of GnRH and regulates transcriptional expression of GnRH in rats [187]. Transcription factor POU5F1 is important for oocytes, zygotes and embryos. For example, it is crucial for blastocyst formation in bovine embryos [188]. Transcription factor NFAT5 is differentially expressed in the hypothalamus of post-pubertal as compared to pre-pubertal Brahman cows [43] and SNPs associated with this gene are also associated with age at menarche in humans [189]. The gene PHTF1 is associated with fertility index in Holstein cattle [190]. The genes HDAC4, a histone deacetylase, is reported to remodulate the male chromatin within oocytes to proceed for development of normal zygotes after fertilization [191]. In short, the role of these transcriptions factors in heifer fertility should be further researched.

\section{Conclusions}

The multi-trait meta-analysis allowed us to identify significant SNPs and propose positional candidate genes. Mining the list of candidate genes for biological function led to an integrated view of signaling mechanisms in the hypothalamus, pituitary and ovarian tissues that are of known importance for fertility and might contribute to the studied heifer traits. Further validation of the identified SNPs is required.

Supplementary Materials: The following are available online at https: / www.mdpi.com/article / 10.3390/genes12050768/s1, Table S1: Distribution of animals for combined datasets of early reproductive traits. Table S2: Significant SNPs Resulting from Muti-Trait Meta-analysis of Three Early Reproductive Traits. Table S3: Genes Mapped within 0.5 MB Region of Significant SNPs; Representative Biological Pathways of the Genes; Transcription Factors; and Genes Common between Multi-Trait Meta-analysis and Transcriptomics and Proteomics. Table S4: DAVID Classified KEGG and GOTERM Biological Pathways.

Author Contributions: Conceptualization, M.R.S.F. and M.S.T.; methodology, M.R.S.F., G.C.G. and M.S.T.; software, M.R.S.F., M.S.T., L.R.P.-N., C.G., O.B.S., G.C.G., A.W.L.T. and H.R.S.; validation, M.R.S.F. and M.S.T.; formal analysis, M.S.T.; investigation, M.S.T., M.R.S.F.; resources, M.R.S.F., J.K., K.W.; data curation, M.R.S.F., J.K., K.W. and L.R.P.-N.; writing-original draft preparation, M.S.T; writing—review and editing, M.R.S.F.; supervision, M.R.S.F.; project administration, M.R.S.F.; funding acquisition, M.R.S.F. All authors have read and agreed to the published version of the manuscript.

Funding: This research was conducted using resources of project "Female Fertility Phenobank" funded by Meat Livestock Australia (MLA), grant number L.GEN 1710".

Acknowledgments: Meat Livestock Australia (MLA) for funding the project "Female Fertility Phenobank (L.GEN 1710)". Commonwealth Scientific and Industrial Research Organization (CSIRO) for providing PhD Top-up scholarship and computational resources for data analysis. The biological pathways figures were created with BioRender.com.

Conflicts of Interest: The authors declare no conflict of interest. The funders had no role in the design of the study; in the collection, analyses, or interpretation of data; in the writing of the manuscript, or in the decision to publish the results.

\section{References}

1. Diskin, M.; Kenny, D. Optimising reproductive performance of beef cows and replacement heifers. Animals 2014, 8, 27-39. [CrossRef]

2. Johnston, D.J.; Barwick, S.A.; Fordyce, G.; Holroyd, R.G.; Williams, P.J.; Corbet, N.J.; Grant, T. Genetics of early and lifetime annual reproductive performance in cows of two tropical beef genotypes in northern Australia. Anim. Prod. Sci. 2014, 54, 1-15. [CrossRef] 
3. Chase, C.C.; Chenoweth, P.J.; Larsen, R.E.; Hammond, A.C.; Olson, T.A.; West, R.L.; Johnson, D.D. Growth, puberty, and carcass characteristics of Brahman-, Senepol-, and Tuli-sired F1 Angus bulls. J. Anim. Sci. 2001, 79, 2006-2015. [CrossRef] [PubMed]

4. Evans, N.P.; Dahl, G.E.; Glover, B.H.; Karsch, F.J. Central regulation of pulsatile gonadotropin-releasing hormone (GnRH) secretion by estradiol during the period leading up to the preovulatory GnRH surge in the ewe. Endocrinology 1994, 134, $1806-1811$. [CrossRef] [PubMed]

5. Dubois, S.L.; Wolfe, A.; Radovick, S.; Boehm, U.; Levine, J.E. Estradiol Restrains Prepubertal Gonadotropin Secretion in Female Mice via Activation of ER $\alpha$ in Kisspeptin Neurons. Endocrinology 2016, 157, 1546-1554. [CrossRef] [PubMed]

6. Iremonger, K.J.; Constantin, S.; Liu, X.; Herbison, A.E. Glutamate regulation of GnRH neuron excitability. Brain Res. 2010, 1364, 35-43. [CrossRef]

7. Krsmanovic, L.Z.; Hu, L.; Leung, P.-K.; Feng, H.; Catt, K.J. The hypothalamic GnRH pulse generator: Multiple regulatory mechanisms. Trends Endocrinol. Metab. 2009, 20, 402-408. [CrossRef]

8. Clarkson, J.; De Tassigny, X.D.; Moreno, A.S.; Colledge, W.H.; Herbison, A.E. Kisspeptin-GPR54 Signaling Is Essential for Preovulatory Gonadotropin-Releasing Hormone Neuron Activation and the Luteinizing Hormone Surge. J. Neurosci. 2008, 28, 8691-8697. [CrossRef]

9. Clarkson, J.; Herbison, A.E. Development of GABA and glutamate signaling at the GnRH neuron in relation to puberty. Mol. Cell. Endocrinol. 2006, 254-255, 32-38. [CrossRef]

10. Arai, Y.; Ishii, H.; Kobayashi, M.; Ozawa, H. Subunit profiling and functional characteristics of acetylcholine receptors in GT1-7 cells. J. Physiol. Sci. 2017, 67, 313-323. [CrossRef] [PubMed]

11. De La Escalera, G.M. Dopaminergic regulation of the GT1 gonadotropin-releasing hormone (GnRH) neuronal cell lines: Stimulation of GnRH release via D1- receptors positively coupled to adenylate cyclase. Endocrinology 1992, 131, 2965-2971. [CrossRef] [PubMed]

12. Shi, B.; Mahesh, V.B.; Bhat, G.K.; Ping, L.; Brann, D.W. Evidence for a role of bradykinin neurons in the control of gonadotropinreleasing hormone secretion. Neuroendocrinology 1998, 67, 209-218. [CrossRef] [PubMed]

13. Macrae, M.B.; Davidson, J.S.; Millar, R.P.; A Van Der Merwe, P. Cyclic AMP stimulates luteinizing-hormone (lutropin) exocytosis in permeabilized sheep anterior-pituitary cells. Synergism with protein kinase C and calcium. Biochem. J. 1990, 271, 635-639. [CrossRef] [PubMed]

14. Pawson, A.J.; McNeilly, A.S. The pituitary effects of GnRH. Anim. Reprod. Sci. 2005, 88, 75-94. [CrossRef] [PubMed]

15. Cammack, K.; Thomas, M.; Enns, R. Reproductive Traits and Their Heritabilities in Beef Cattle. Prof. Anim. Sci. 2009, 25, 517-528. [CrossRef]

16. Porto-Neto, L.R.; Edwards, S.; Fortes, M.R.S.; Lehnert, S.A.; Reverter, A.; McGowan, M.; Porto-Neto, L. Genome-wide association for the outcome of fixed-time artificial insemination of Brahman heifers in northern Australia. J. Anim. Sci. 2015, 93, 5119-5127. [CrossRef] [PubMed]

17. Hawken, R.J.; Zhang, Y.D.; Fortes, M.R.S.; Collis, E.; Barris, W.C.; Corbet, N.J.; Williams, P.J.; Fordyce, G.; Holroyd, R.G.; Walkley, J.R.W.; et al. Genome-wide association studies of female reproduction in tropically adapted beef cattle. J. Anim. Sci. 2012, 90, 1398-1410. [CrossRef]

18. Irano, N.; De Camargo, G.M.F.; Costa, R.B.; Terakado, A.P.N.; Magalhães, A.F.B.; Silva, R.M.D.O.; Dias, M.M.; Bignardi, A.B.; Baldi, F.; Carvalheiro, R.; et al. Genome-Wide Association Study for Indicator Traits of Sexual Precocity in Nellore Cattle. PLoS ONE 2016, 11, e0159502. [CrossRef]

19. Stahl, E.A.; BIRAC Consortium; Raychaudhuri, S.; Remmers, E.F.; Xie, G.; Eyre, S.; Thomson, B.P.; Li, Y.; Kurreeman, F.A.S.; Zhernakova, A.; et al. Genome-wide association study meta-analysis identifies seven new rheumatoid arthritis risk loci. Nat. Genet. 2010, 42, 508-514. [CrossRef]

20. Manolio, T.A.; Collins, F.S.; Cox, N.J.; Goldstein, D.B.; Hindorff, L.A.; Hunter, D.J.; McCarthy, M.I.; Ramos, E.M.; Cardon, L.R.; Chakravarti, A.; et al. Finding the missing heritability of complex diseases. Nat. Cell Biol. 2009, 461, 747-753. [CrossRef]

21. Gibson, G. Hints of hidden heritability in GWAS. Nat. Genet. 2010, 42, 558-560. [CrossRef] [PubMed]

22. Visscher, P.M.; Hemani, G.; Vinkhuyzen, A.A.E.; Chen, G.-B.; Lee, S.H.; Wray, N.R.; Goddard, M.E.; Yang, J. Statistical Power to Detect Genetic (Co)Variance of Complex Traits Using SNP Data in Unrelated Samples. PLoS Genet. 2014, 10, e1004269. [CrossRef] [PubMed]

23. Nakagawa, S.; Santos, E.S.A. Methodological issues and advances in biological meta-analysis. Evol. Ecol. 2012, 26, 1253-1274. [CrossRef]

24. Melo, T.P.; Fortes, M.R.S.; Bresolin, T.; Mota, L.F.M.; Albuquerque, L.G.; Carvalheiro, R. Multitrait meta-analysis identified genomic regions associated with sexual precocity in tropical beef cattle. J. Anim. Sci. 2018, 96, 4087-4099. [CrossRef]

25. Xiang, R.; Berg, I.V.D.; MacLeod, I.M.; Daetwyler, H.D.; Goddard, M.E. Effect direction meta-analysis of GWAS identifies extreme, prevalent and shared pleiotropy in a large mammal. Commun. Biol. 2020, 3, 1-14. [CrossRef]

26. Loh, P.-R.; Danecek, P.; Palamara, P.F.; Fuchsberger, C.; A Reshef, Y.; Finucane, H.K.; Schoenherr, S.; Forer, S.S.L.; McCarthy, S.; Abecasis, C.F.G.R.; et al. Reference-based phasing using the Haplotype Reference Consortium panel. Nat. Genet. 2016, 48, 1443-1448. [CrossRef]

27. Das, S.; Forer, L.; Schönherr, S.; Sidore, C.; E Locke, A.; Kwong, A.; I Vrieze, S.; Chew, E.Y.; Levy, S.; McGue, M.; et al. Next-generation genotype imputation service and methods. Nat. Genet. 2016, 48, 1284-1287. [CrossRef] 
28. Purcell, S.; Neale, B.; Todd-Brown, K.; Thomas, L.; Ferreira, M.A.R.; Bender, D.; Maller, J.; Sklar, P.; de Bakker, P.I.W.; Daly, M.J.; et al. PLINK: A Tool Set for Whole-Genome Association and Population-Based Linkage Analyses. Am. J. Hum. Genet. 2007, 81, 559-575. [CrossRef]

29. Danecek, P.; Auton, A.; Abecasis, G.; Albers, C.A.; Banks, E.; DePristo, M.A.; Handsaker, R.E.; Lunter, G.; Marth, G.T.; Sherry, S.T.; et al. The variant call format and VCFtools. Bioinformatics 2011, 27, 2156-2158. [CrossRef]

30. Hawlader, A.A.; Bernardes, P.A.; Lim, D.; Park, B.; Gondro, C. A guide to imputation of low density single nucleotide polymorphism data up to sequence level. J. Anim. Breed. Genomics 2017, 1, 59-68.

31. Golden Helix, I. SNP \& Variation Suite ${ }^{\mathrm{TM}}$ [Software]. [(Version 8.x)]. Available online: http:/ /www.goldenhelix.com (accessed on 15 May 2020).

32. Zhang, Y.D.; Johnston, D.J.; Bolormaa, S.; Hawken, R.J.; Tier, B. Genomic selection for female reproduction in Australian tropically adapted beef cattle. Anim. Prod. Sci. 2014, 54, 16-24. [CrossRef]

33. Sarup, P.; Jensen, J.; Ostersen, T.; Henryon, M.; Sørensen, P. Increased prediction accuracy using a genomic feature model including prior information on quantitative trait locus regions in purebred Danish Duroc pigs. BMC Genet. 2016, 17, 1-16. [CrossRef] [PubMed]

34. Vanvanhossou, S.F.U.; Scheper, C.; Dossa, L.H.; Yin, T.; Brügemann, K.; König, S. A multi-breed GWAS for morphometric traits in four Beninese indigenous cattle breeds reveals loci associated with conformation, carcass and adaptive traits. BMC Genom. 2020, 21, 1-16. [CrossRef] [PubMed]

35. Bolormaa, S.; Pryce, J.E.; Reverter, A.; Zhang, Y.; Barendse, W.; Kemper, K.; Tier, B.; Savin, K.; Hayes, B.J.; Goddard, M.E. A Multi-Trait, Meta-analysis for Detecting Pleiotropic Polymorphisms for Stature, Fatness and Reproduction in Beef Cattle. PLoS Genet. 2014, 10, e1004198. [CrossRef] [PubMed]

36. Benjamini, Y.; Hochberg, Y. Controlling the False Discovery Rate: A Practical and Powerful Approach to Multiple Testing. J. R. Stat. Soc. Ser. B 1995, 57, 289-300. [CrossRef]

37. Pereira, A.G.T.; Utsunomiya, Y.T.; Milanesi, M.; Torrecilha, R.B.P.; Carmo, A.S.; Neves, H.H.R.; Carvalheiro, R.; Ajmone-Marsan, P.; Sonstegard, T.S.; Sölkner, J.; et al. Pleiotropic Genes Affecting Carcass Traits in Bos indicus (Nellore) Cattle Are Modulators of Growth. PLoS ONE 2016, 11, e0158165. [CrossRef]

38. McKay, S.D.; Schnabel, R.D.; Murdoch, B.M.; Matukumalli, L.K.; Aerts, J.; Coppieters, W.; Crews, D.; Neto, E.D.; Gill, C.A.; Gao, C.; et al. Whole genome linkage disequilibrium maps in cattle. BMC Genet. 2007, 8, 1-12. [CrossRef]

39. Rosen, B.D.; Bickhart, D.M.; Schnabel, R.D.; Koren, S.; Elsik, C.G.; Tseng, E.; Rowan, T.N.; Low, W.Y.; Zimin, A.; Couldrey, C.; et al. De novo assembly of the cattle reference genome with single-molecule sequencing. GigaScience 2020, 9, 1-9. [CrossRef]

40. Huang, D.W.; Sherman, B.T.; Lempicki, R.A. Systematic and integrative analysis of large gene lists using DAVID bioinformatics resources. Nat. Protoc. 2009, 4, 44-57. [CrossRef]

41. Huang, D.W.; Sherman, B.T.; Lempicki, R.A. Bioinformatics enrichment tools: Paths toward the comprehensive functional analysis of large gene lists. Nucleic Acids Res. 2009, 37, 1-13. [CrossRef]

42. Guney, E.; Oliva, B. Exploiting Protein-Protein Interaction Networks for Genome-Wide Disease-Gene Prioritization. PLoS ONE 2012, 7, e43557. [CrossRef] [PubMed]

43. Fortes, M.R.S.; Nguyen, L.T.; Weller, M.M.D.C.A.; Cánovas, A.; Islas-Trejo, A.; Porto-Neto, L.R.; Reverter, A.; Lehnert, S.A.; Boe-Hansen, G.B.; Thomas, M.G.; et al. Transcriptome analyses identify five transcription factors differentially expressed in the hypothalamus of post-versus prepubertal Brahman heifers. J. Anim. Sci. 2016, 94, 3693-3702. [CrossRef] [PubMed]

44. Nguyen, L.T.; Reverter, A.; Cánovas, A.; Venus, B.; Islas-Trejo, A.; Porto-Neto, L.R.; Lehnert, S.A.; Medrano, J.F.; Moore, S.S.; Fortes, M.R.S. Global differential gene expression in the pituitary gland and the ovaries of pre- and postpubertal Brahman heifers. J. Anim. Sci. 2017, 95, 599-615. [CrossRef]

45. Fortes, M.R.S.; Zacchi, L.F.; Nguyen, L.T.; Raidan, F.; Weller, M.M.D.C.A.; Choo, J.J.Y.; Reverter, A.; Rego, J.P.A.; Boe-Hansen, G.B.; Porto-Neto, L.R.; et al. Pre- and post-puberty expression of genes and proteins in the uterus of Bos indicus heifers: The luteal phase effect post-puberty. Anim. Genet. 2018, 49, 539-549. [CrossRef] [PubMed]

46. Roider, H.G.; Manke, T.; O'Keeffe, S.; Vingron, M.; Haas, S.A. PASTAA: Identifying transcription factors associated with sets of co-regulated genes. Bioinformatics 2009, 25, 435-442. [CrossRef] [PubMed]

47. Zhang, C.; Roepke, T.A.; Kelly, M.J.; Rønnekleiv, O.K. Kisspeptin Depolarizes Gonadotropin-Releasing Hormone Neurons through Activation of TRPC-Like Cationic Channels. J. Neurosci. 2008, 28, 4423-4434. [CrossRef]

48. Zhang, X.-B.; Spergel, D.J. Kisspeptin Inhibits High-Voltage Activated Ca2+Channels in GnRH Neurons via Multiple Ca2+Influx and Release Pathways. Neuroendocrinology 2012, 96, 68-80. [CrossRef]

49. Zhang, C.; Bosch, M.A.; Rønnekleiv, O.K.; Kelly, M.J. Kisspeptin Activation of TRPC4 Channels in Female GnRH Neurons Requires PIP2 Depletion and cSrc Kinase Activation. Endocrinology 2013, 154, 2772-2783. [CrossRef] [PubMed]

50. Hemond, P.J.; O’Boyle, M.P.; Roberts, C.B.; Delgado-Reyes, A.; Hemond, Z.; Suter, K.J. Simulated GABA Synaptic Input and LType Calcium Channels Form Functional Microdomains in Hypothalamic Gonadotropin-Releasing Hormone Neurons. J. Neurosci. 2012, 32, 8756-8766. [CrossRef]

51. Padgett, C.L.; Slesinger, P.A. GABAB Receptor Coupling to G-proteins and Ion Channels. In Advances in Pharmacology; Elsevier BV: Amsterdam, The Netherlands, 2010; Volume 58, pp. 123-147.

52. Kornau, H.C. GABA(B) receptors and synaptic modulation. Cell Tissue Res. 2006, 326, 517-533. [CrossRef] 
53. Jacob, T.C.; Moss, S.J.; Jurd, R. GABA(A) receptor trafficking and its role in the dynamic modulation of neuronal inhibition. Nat. Rev. Neurosci. 2008, 9, 331-343. [CrossRef]

54. Chalifoux, J.R.; Carter, A.G. GABAB receptor modulation of synaptic function. Curr. Opin. Neurobiol. 2011, 21, 339-344. [CrossRef] [PubMed]

55. Ferraguti, F.; Crepaldi, L.; Nicoletti, F. Metabotropic Glutamate 1 Receptor: Current Concepts and Perspectives. Pharmacol. Rev. 2008, 60, 536-581. [CrossRef] [PubMed]

56. Palmada, M.; Centelles, J.J. Excitatory amino acid neurotransmission. Pathways for metabolism, storage and reuptake of glutamate in brain. Front. Biosci. 1998, 3, d701-d718. [PubMed]

57. Schoepp, D.D. Unveiling the functions of presynaptic metabotropic glutamate receptors in the central nervous system. J. Pharmacol. Exp. Ther. 2001, 299, 12-20.

58. Conti, F.; Weinberg, R.J. Shaping excitation at glutamatergic synapses. Trends Neurosci. 1999, 22, 451-458. [CrossRef]

59. Novaira, H.J.; Ng, Y.; Wolfe, A.; Radovick, S. Kisspeptin increases GnRH mRNA expression and secretion in GnRH secreting neuronal cell lines. Mol. Cell. Endocrinol. 2009, 311, 126-134. [CrossRef]

60. Szereszewski, J.M.; Pampillo, M.; Ahow, M.R.; Offermanns, S.; Bhattacharya, M.; Babwah, A.V. GPR54 regulates ERK1/2 activity and hypothalamic gene expression in a G $\alpha$ q/11 and $\beta$-arrestin-dependent manner. PLoS ONE 2010, 5, e12964. [CrossRef]

61. Caulfield, M.P.; Birdsall, N.J. International Union of Pharmacology. XVII. Classification of muscarinic acetylcholine receptors. Pharmacol. Rev. 1998, 50, 279-290.

62. Kaneishi, K.; Sakuma, Y.; Kobayashi, H.; Kato, M. 3',5'-Cyclic Adenosine Monophosphate Augments Intracellular Ca2+ Concentration and Gonadotropin-Releasing Hormone (GnRH) Release in Immortalized GnRH Neurons in an Na+-Dependent Manner. Endocrinology 2002, 143, 4210-4217. [CrossRef]

63. Sakakibara, H.; Conti, M.; Weiner, R. Role of Phosphodiesterases in the Regulation of Gonadotropin- Releasing Hormone Secretion in GT1 Cells. Neuroendocrinology 1998, 68, 365-373. [CrossRef] [PubMed]

64. Vitalis, E.A.; Costantin, J.L.; Tsai, P.-S.; Sakakibara, H.; Paruthiyil, S.; Iiri, T.; Martini, J.-F.; Taga, M.; Choi, A.L.H.; Charles, A.C.; et al. Role of the cAMP signaling pathway in the regulation of gonadotropin-releasing hormone secretion in GT1 cells. Proc. Natl. Acad. Sci. USA 2000, 97, 1861-1866. [CrossRef] [PubMed]

65. Vazquez-Martinez, R.; Shorte, S.L.; Faught, W.J.; Leaumont, D.C.; Frawley, L.S.; Boockfor, F.R. Pulsatile exocytosis is functionally associated with GnRH gene expression in immortalized GnRH-expressing cells. Endocrinology 2001, 142, 5364-5370. [CrossRef] [PubMed]

66. Rønnekleiv, O.K.; Bosch, M.A.; Zhang, C. Regulation of endogenous conductances in GnRH neurons by estrogens. Brain Res. 2010, 1364, 25-34. [CrossRef]

67. Biorender. Available online: www.biorender.com.

68. Ruf, F.; Sealfon, S.C. Genomics view of gonadotrope signaling circuits. Trends Endocrinol. Metab. 2004, 15, 331-338. [CrossRef]

69. Naor, Z.; Benard, O.; Seger, R. Activation of MAPK Cascades by G-protein-coupled Receptors: The Case of Gonadotropin-releasing Hormone Receptor. Trends Endocrinol. Metab. 2000, 11, 91-99. [CrossRef]

70. Kraus, S.; Naor, Z.; Seger, R. Intracellular Signaling Pathways Mediated by the Gonadotropin-Releasing Hormone (GnRH) Receptor. Arch. Med. Res. 2001, 32, 499-509. [CrossRef]

71. Bliss, S.P.; Navratil, A.M.; Xie, J.; Roberson, M.S. GnRH signaling, the gonadotrope and endocrine control of fertility. Front. Neuroendocr. 2010, 31, 322-340. [CrossRef]

72. Haisenleder, D.J.; Ferris, H.A.; Shupnik, M.A. The Calcium Component of Gonadotropin-Releasing Hormone-Stimulated Luteinizing Hormone Subunit Gene Transcription Is Mediated by Calcium/Calmodulin-Dependent Protein Kinase Type II. Endocrinology 2003, 144, 2409-2416. [CrossRef]

73. Hehl, S.; Golard, A.; Hille, B. Involvement of mitochondria in intracellular calcium sequestration by rat gonadotropes. Cell Calcium 1996, 20, 515-524. [CrossRef]

74. Poulin, B.; Rich, N.; Mitev, Y.; Gautron, J.P.; Kordon, C.; Enjalbert, A.; Drouva, S.V. Differential involvement of calcium channels and protein kinase-C activity in GnRH-induced phospholipase-C, -A2 and -D activation in a gonadotrope cell line ( $\alpha \mathrm{T} 3-1)$. Mol. Cell. Endocrinol. 1996, 122, 33-50. [CrossRef]

75. Bernard, D.J.; Tran, S. Mechanisms of Activin-Stimulated FSH Synthesis: The Story of a Pig and a Fox. Biol. Reprod. 2013, 88, 78. [CrossRef]

76. Vanecek, J. Inhibitory effect of melatonin on GnRH-induced LH release. Rev. Reprod. 1999, 4, 67-72. [CrossRef]

77. Durán-Pastén, M.L.; Fiordelisio, T. GnRH-induced Ca2+ signaling patterns and gonadotropin secretion in pituitary gonadotrophs. Functional adaptations to both ordinary and extraordinary physiological demands. Front. Endocrinol. 2013, 4, 127. [CrossRef] [PubMed]

78. Wood, J.R.; Strauss, J.F., 3rd. Multiple signal transduction pathways regulate ovarian steroidogenesis. Rev. Endocr. Metab. Disord. 2002, 3, 33-46. [CrossRef] [PubMed]

79. Young, J.M.; McNeilly, A.S. Theca: The forgotten cell of the ovarian follicle. Reproduction 2010, 140, 489-504. [CrossRef] [PubMed]

80. Wang, X.; Stocco, D.M. Cyclic AMP and arachidonic acid: A tale of two pathways. Mol. Cell. Endocrinol. 1999, 158, 7-12. [CrossRef] 
81. Wang, X.; Shen, C.L.; Dyson, M.T.; Yin, X.; Schiffer, R.B.; Grammas, P.; Stocco, D.M. The involvement of epoxygenase metabolites of arachidonic acid in CAMP-stimulated steroidogenesis and steroidogenic acute regulatory protein gene expression. J. Endocrinol. 2006, 190, 871-878. [CrossRef] [PubMed]

82. Miyoshi, T.; Otsuka, F.; Inagaki, K.; Otani, H.; Takeda, M.; Suzuki, J.; Goto, J.; Ogura, T.; Makino, H. Differential Regulation of Steroidogenesis by Bone Morphogenetic Proteins in Granulosa Cells: Involvement of Extracellularly Regulated Kinase Signaling and Oocyte Actions in Follicle-Stimulating Hormone-Induced Estrogen Production. Endocrinology 2007, 148, 337-345. [CrossRef]

83. Shimasaki, S.; Moore, R.K.; Otsuka, F.; Erickson, G.F. The Bone Morphogenetic Protein System in Mammalian Reproduction. Endocr. Rev. 2004, 25, 72-101. [CrossRef] [PubMed]

84. Drummond, A.E. The role of steroids in follicular growth. Reprod. Biol. Endocrinol. 2006, 4, 16. [CrossRef] [PubMed]

85. Schmitt, A.; Nebreda, A.R. Signalling pathways in oocyte meiotic maturation. J. Cell Sci. 2002, 115, 2457-2459. [CrossRef] [PubMed]

86. Nebreda, A.R.; Ferby, I. Regulation of the meiotic cell cycle in oocytes. Curr. Opin. Cell Biol. 2000, 12, 666-675. [CrossRef]

87. Andersen, C.B.; Sakaue, H.; Nedachi, T.; Kovacina, K.S.; Clayberger, C.; Conti, M.; Roth, R.A. Protein kinase B/Akt is essential for the insulin- but not progesterone-stimulated resumption of meiosis in Xenopus oocytes. Biochem. J. 2003, 369, 227-238. [CrossRef]

88. Duckworth, B.C.; Weaver, J.S.; Ruderman, J.V. G2 arrest in Xenopus oocytes depends on phosphorylation of cdc25 by protein kinase A. Proc. Natl. Acad. Sci. USA 2002, 99, 16794-16799. [CrossRef]

89. Abrieu, A.; Doree, M.; Fisher, D. The interplay between cyclin-B-Cdc2 kinase (MPF) and MAP kinase during maturation of oocytes. J. Cell Sci. 2001, 114, 257-267. [CrossRef]

90. Cavani, L.; Garcia, D.A.; Carreño, L.O.D.; Ono, R.K.; Pires, M.P.; Farah, M.M.; Ventura, H.T.; Millen, D.D.; Fonseca, R. Estimates of genetic parameters for reproductive traits in Brahman cattle breed. J. Anim. Sci. 2015, 93, 3287-3291. [CrossRef]

91. Perry, J.R.B.; Stolk, L.; Franceschini, N.; Lunetta, K.L.; Zhai, G.; McArdle, P.F.; Smith, A.V.; Aspelund, T.; Bandinelli, S.; Boerwinkle, E.; et al. Meta-analysis of genome-wide association data identifies two loci influencing age at menarche. Nat. Genet. 2009, 41, 648-650. [CrossRef]

92. Mills, M.C.; Tropf, F.C.; Brazel, D.M.; Van Zuydam, N.; Vaez, A.; Pers, T.H.; Snieder, H.; Perry, J.R.; Ong, K.K.; Den Hoed, M.; et al. Identification of 370 loci for age at onset of sexual and reproductive behaviour, highlighting common aetiology with reproductive biology, externalizing behaviour and longevity. BioRxiv 2020. [CrossRef]

93. Cousminer, D.L.; Stergiakouli, E.; Berry, D.J.; Ang, W.; Groen-Blokhuis, M.M.; Körner, A.; Siitonen, N.; Ntalla, I.; Marinelli, M.; Perry, J.R.; et al. Genome-wide association study of sexual maturation in males and females highlights a role for body mass and menarche loci in male puberty. Hum. Mol. Genet. 2014, 23, 4452-4464. [CrossRef]

94. Weller, J.; Bickhart, D.; Wiggans, G.; Tooker, M.; O'Connell, J.; Jiang, J.; Ron, M.; VanRaden, P. Determination of quantitative trait nucleotides by concordance analysis between quantitative trait loci and marker genotypes of US Holsteins. J. Dairy Sci. 2018, 101, 9089-9107. [CrossRef]

95. Höglund, J.K.; Buitenhuis, B.; Guldbrandtsen, B.; Lund, M.S.; Sahana, G. Genome-wide association study for female fertility in Nordic Red cattle. BMC Genet. 2015, 16, 1-11. [CrossRef]

96. Tahir, M.S.; Nguyen, L.T.; Schulz, B.L.; Boe-Hansen, G.A.; Thomas, M.G.; Moore, S.S.; Lau, L.Y.; Fortes, M.R.S. Proteomics Recapitulates Ovarian Proteins Relevant to Puberty and Fertility in Brahman Heifers (Bos indicus L.). Genes 2019, 10, 923. [CrossRef] [PubMed]

97. Fernández, J.; Perez, J.E.; Herrera, N.; Martinez, R.; Bejarano, D.; Rocham, J.F. Genomic association study for age at first calving and calving interval in Romosinuano and Costeño con Cuernos cattle. Genet. Mol. Res. 2019. [CrossRef]

98. Tomiyama, H. A Commentary on Axon guidance pathway genes and Parkinson's disease. J. Hum. Genet. 2010, 56, 102-103. [CrossRef] [PubMed]

99. Liu, W.; Xin, Q.; Wang, X.; Wang, S.; Wang, H.; Zhang, W.; Yang, Y.; Zhang, Y.; Zhang, Z.; Wang, C.; et al. Estrogen receptors in granulosa cells govern meiotic resumption of pre-ovulatory oocytes in mammals. Cell Death Dis. 2017, 8, e2662. [CrossRef] [PubMed]

100. Rumi, M.K.; Singh, P.; Roby, K.F.; Zhao, X.; Iqbal, K.; Ratri, A.; Lei, T.; Cui, W.; Borosha, S.; Dhakal, P.; et al. Defining the Role of Estrogen Receptor beta in the Regulation of Female Fertility. Endocrinology 2017, 158, 2330-2343. [CrossRef]

101. Lang-Muritano, M.; Sproll, P.; Wyss, S.; Kolly, A.; Hürlimann, R.; Konrad, D.; Biason-Lauber, A. Early-Onset Complete Ovarian Failure and Lack of Puberty in a Woman with Mutated Estrogen Receptor $\beta$ (ESR2). J. Clin. Endocrinol. Metab. 2018, 103, 3748-3756. [CrossRef] [PubMed]

102. Antonson, P.; Apolinário, L.M.; Shamekh, M.M.; Humire, P.; Poutanen, M.; Ohlsson, C.; Nalvarte, I.; Gustafsson, J.-Å. Generation of an all-exon Esr2 deleted mouse line: Effects on fertility. Biochem. Biophys. Res. Commun. 2020, 529, 231-237. [CrossRef]

103. E Irwin, R.; Pentieva, K.; Cassidy, T.; Lees-Murdock, D.J.; McLaughlin, M.; Prasad, G.; McNulty, H.; Walsh, C.P. The interplay between DNA methylation, folate and neurocognitive development. Epigenomics 2016, 8, 863-879. [CrossRef]

104. Südhof, T.C.; Rizo, J. Synaptic Vesicle Exocytosis. Cold Spring Harb. Perspect. Biol. 2011, 3, a005637. [CrossRef]

105. Burgoyne, R.D. Secretory Vesicle-Associated Proteins and Their Role in Exocytosis. Annu. Rev. Physiol. 1990, 52, 647-659. [CrossRef] [PubMed]

106. Krsmanovic, L.Z.; Stojilkovic, S.S.; Balla, T.; Al-Damluji, S.; Weiner, R.I.; Catt, K.J. Receptors and neurosecretory actions of endothelin in hypothalamic neurons. Proc. Natl. Acad. Sci. USA 1991, 88, 11124-11128. [CrossRef] 
107. Han, S.-K.; Gottsch, M.L.; Lee, K.J.; Popa, S.M.; Smith, J.T.; Jakawich, S.K.; Clifton, D.K.; Steiner, R.A.; Herbison, A. Activation of Gonadotropin-Releasing Hormone Neurons by Kisspeptin as a Neuroendocrine Switch for the Onset of Puberty. J. Neurosci. 2005, 25, 11349-11356. [CrossRef]

108. Clarke, I.J. Control of GnRH secretion: One step back. Front. Neuroendocr. 2011, 32, 367-375. [CrossRef] [PubMed]

109. Roy, D.; Belsham, D.D. Melatonin receptor activation regulates GnRH gene expression and secretion in GT1-7 GnRH neurons signal transduction mechanisms. J. Biol. Chem. 2002, 277, 251-258. [CrossRef] [PubMed]

110. Bootman, M.D.; Collins, T.J.; Peppiatt, C.M.; Prothero, L.S.; MacKenzie, L.; De Smet, P.; Travers, M.; Tovey, S.C.; Seo, J.T.; Berridge, M.J.; et al. Calcium signalling-An overview. In Seminars in Cell \& Developmental Biology; Elsevier: Amsterdam, The Netherlands, 2001.

111. Liu, X.; Lee, K.; Herbison, A.E. Kisspeptin Excites Gonadotropin-Releasing Hormone Neurons through a Phospholipase C/Calcium-Dependent Pathway Regulating Multiple Ion Channels. Endocrinology 2008, 149, 4605-4614. [CrossRef]

112. Krsmanovic, L.Z.; Stojilkovic, S.S.; Merelli, F.; Dufour, S.M.; Virmani, M.A.; Catt, K.J. Calcium signaling and episodic secretion of gonadotropin-releasing hormone in hypothalamic neurons. Proc. Natl. Acad. Sci. USA 1992, 89, 8462-8466. [CrossRef]

113. Spergel, D.J.; Krsmanović, L.Z.; Stojilkovic, S.S.; Catt, K.J. L-Type Ca2+ Channels Mediate Joint Modulation by Gamma-Aminobutyric Acid and Glutamate of $\left[\mathrm{Ca}^{2+}\right]_{i}$ and Neuropeptide Secretion in Immortalized Gonadodropin-Releasing Hormone Neurons. Neuroendocrinology 1995, 61, 499-508. [CrossRef]

114. Sun, Y.; Sukumaran, P.; Bandyopadhyay, B.C.; Singh, B.B. Physiological Function and Characterization of TRPCs in Neurons. Cells 2014, 3, 455-475. [CrossRef]

115. Dalmazzo, S.; Antoniotti, S.; Ariano, P.; Gilardino, A.; Lovisolo, D. Expression and localisation of TRPC channels in immortalised GnRH neurons. Brain Res. 2008, 1230, 27-36. [CrossRef]

116. Salido, G.M.; Jardín, I.; Rosado, J.A. The TRPC ion Channels: Association with Orai1 and STIM1 Proteins and Participation in Capacitative and Non-Capacitative Calcium Entry. In Transient Receptor Potential Channels; Springer: Berlin, Germany, 2011; pp. 413-433.

117. Kelly, M.J.; Qiu, J.; Rønnekleiv, O.K. TRPCing around the hypothalamus. Front. Neuroendocr. 2018, 51, 116-124. [CrossRef]

118. Naghdi, S.; Hajnóczky, G. VDAC2-specific cellular functions and the underlying structure. Biochim. Biophys. Acta Bioenerg. 2016, 1863, 2503-2514. [CrossRef] [PubMed]

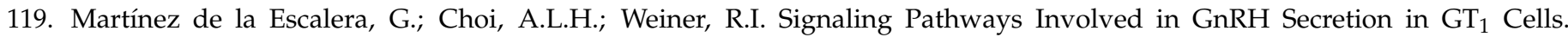
Neuroendocrinology 1995, 61, 310-317. [CrossRef] [PubMed]

120. Weiner, R.I.; Charles, A. Regulation of gonadotropinmreleasing hormone release by cyclic AMP signalling pathways. Growth Horm. Igf Res. 2001, 11, S9-S15. [CrossRef]

121. Barrachina, M.; Martín, M.; Ciruela, F.; Ferrer, F.C.A.I. Epigenetic Modulation of Adenosine A2A Receptor: A Putative Therapeutical Tool for the Treatment of Parkinson's Disease. New Ther. Parkinson's Dis. 2011, 295-312. [CrossRef]

122. Vastagh, C.; Rodolosse, A.; Solymosi, N.; Liposits, Z. Altered Expression of Genes Encoding Neurotransmitter Receptors in GnRH Neurons of Proestrous Mice. Front. Cell. Neurosci. 2016, 10, 230. [CrossRef]

123. Mohammadi, A.; Alijani, S.; Rafat, S.A.; Abdollahi-Arpanahi, R. Genome-Wide Association Study and Pathway Analysis for Female Fertility Traits in Iranian Holstein Cattle. Ann. Anim. Sci. 2020, 20, 825-851. [CrossRef]

124. Spergel, D.J.; Krsmanovic, L.Z.; Stojilkovic, S.S.; Catt, K.J. Glutamate Modulates $\left[\mathrm{Ca}^{2+}\right]_{\mathrm{i}}$ and Gonadotropin-Releasing Hormone Secretion in Immortalized Hypothalamic GT1-7 Neurons. Neuroendocrinology 1994, 59, 309-317. [CrossRef]

125. O'Connor, V.; El Far, O.; Bofill-Cardona, E.; Nanoff, C.; Freissmuth, M.; Karschin, A.; Airas, J.M.; Betz, H.; Boehm, S. Calmodulin Dependence of Presynaptic Metabotropic Glutamate Receptor Signaling. Science 1999, 286, 1180-1184. [CrossRef]

126. Mahesh, V.B.; Zamorano, P.; De Sevilla, L.; Lewis, D.; Brann, D.W. Characterization of ionotropic glutamate receptors in rat hypothalamus, pituitary and immortalized gonadotropin-releasing hormone (GnRH) neurons (GT1-7 cells). Neuroendocrinology 1999, 69, 397-407. [CrossRef] [PubMed]

127. Sortino, M.A.; Aleppo, G.; Copani, A.; Casabona, G.; Nicoletti, F.; Ventra, C.; Kuhn, R.; Knöpfel, T.; Malitschek, B.; Canonico, P.L. Immortalized Hypothalamic Neurons Express Metabotropic Glutamate Receptors Positively Coupled to Cyclic AMP Formation. Eur. J. Neurosci. 1996, 8, 2407-2415. [CrossRef] [PubMed]

128. Watanabe, M.; Fukuda, A.; Nabekura, J. The role of GABA in the regulation of GnRH neurons. Front. Neurosci. 2014, 8, 387. [CrossRef]

129. Peters, A.; Riley, G. Is the Cow a Seasonal Breeder? Br. Veter J. 1982, 138, 533-537. [CrossRef]

130. Revel, F.G.; Masson-Pévet, M.; Pévet, P.; Mikkelsen, J.D.; Simonneaux, V. Melatonin Controls Seasonal Breeding by a Network of Hypothalamic Targets. Neuroendocrinology 2009, 90, 1-14. [CrossRef] [PubMed]

131. Kelly, M.J.; Qiu, J. Estrogen signaling in hypothalamic circuits controling reproduction. Brain Res. 2010, 1364, 44-52. [CrossRef]

132. Rønnekleiv, O.K.; Kelly, M.J. Kisspeptin Signaling in Reproductice Biology. In Advances in Experimental Medicine and Biology; Kauffman, A.S., Jeremy, S., Eds.; Springer: New York, NY, USA, 2013; pp. 113-131.

133. Ábrahám, I.M.; Han, S.K.; Todman, M.G.; Korach, K.S.; Herbison, A.E. Estrogen receptor beta mediates rapid estrogen actions on gonadotropin-releasing hormone neurons in vivo. J. Neurosci. 2003, 23, 5771-5777. [CrossRef]

134. Hu, L.; Gustofson, R.L.; Feng, H.; Leung, P.K.; Mores, N.; Krsmanovic, L.Z.; Catt, K.J. Converse Regulatory Functions of Estrogen Receptor- $\alpha$ and $-\beta$ Subtypes Expressed in Hypothalamic Gonadotropin-Releasing Hormone Neurons. Mol. Endocrinol. 2008, 22, 2250-2259. [CrossRef] 
135. Amstalden, M.; Williams, G. Kisspeptin neuronal networks in pubertal development of domestic female ruminants. In Bioscientifica Proceedings; Bioscientifica: Bristol, UK, 2019; pp. 127-140.

136. Dedes, I. Kisspeptins and the control of gonadotrophin secretion. Syst. Biol. Reprod. Med. 2012, 58, 121-128. [CrossRef]

137. Kanaya, M.; Higo, S.; Ozawa, H. Neurochemical Characterization of Neurons Expressing Estrogen Receptor $\beta$ in the Hypothalamic Nuclei of Rats Using in Situ Hybridization and Immunofluorescence. Int. J. Mol. Sci. 2019, 21, 115. [CrossRef]

138. Papaoiconomou, E.; Msaouel, P.; Makri, A.; Diamanti-Kandarakis, E.; Koutsilieris, M. The role of kisspeptin/GPR54 in the reproductive system. In Vivo 2011, 25, 343-354. [PubMed]

139. Elias, C.F.; Purohit, D. Leptin signaling and circuits in puberty and fertility. Cell. Mol. Life Sci. 2012, 70, 841-862. [CrossRef]

140. Magni, P.; Vettor, R.; Pagano, C.; Calcagno, A.; Beretta, E.; Messi, E.; Zanisi, M.; Martini, L.; Motta, M. Expression of a leptin receptor in immortalized gonadotropin-releasing hormone-secreting neurons. Endocrinology 1999, 140, 1581-1585. [CrossRef] [PubMed]

141. Gamba, M.; Pralong, F.P. Control of GnRH neuronal activity by metabolic factors: The role of leptin and insulin. Mol. Cell. Endocrinol. 2006, 254-255, 133-139. [CrossRef] [PubMed]

142. Sanchez-Garrido, M.A.; Tena-Sempere, M. Metabolic control of puberty: Roles of leptin and kisspeptins. Horm. Behav. 2013, 64, 187-194. [CrossRef] [PubMed]

143. Nieuwenhuis, D.; Pujol-Gualdo, N.; Arnoldussen, I.A.; Kiliaan, A.J. Adipokines: A gear shift in puberty. Obes. Rev. 2020, 21, e13005. [CrossRef]

144. Berridge, M.J. Inositol trisphosphate and calcium signalling. Nat. Cell Biol. 1993, 361, 315-325. [CrossRef]

145. Tse, A.; Tse, F.W.; Almers, W.; Hille, B. Rhythmic exocytosis stimulated by GnRH-induced calcium oscillations in rat gonadotropes. Science 1993, 260, 82-84. [CrossRef]

146. Fukui, K.; Sasaki, T.; Imazumi, K.; Matsuura, Y.; Nakanishi, H.; Takai, Y. Isolation and Characterization of a GTPase Activating Protein Specific for the Rab3 Subfamily of Small G Proteins. J. Biol. Chem. 1997, 272, 4655-4658. [CrossRef]

147. Senthilkumaran, B.; Yoshikuni, M.; Nagahama, Y. A shift in steroidogenesis occurring in ovarian follicles prior to oocyte maturation. Mol. Cell. Endocrinol. 2004, 215, 11-18. [CrossRef]

148. Stocco, C. Aromatase expression in the ovary: Hormonal and molecular regulation. Steroids 2008, 73, 473-487. [CrossRef] [PubMed]

149. Stocco, D.M.; Wang, X.; Jo, Y.; Manna, P.R. Multiple Signaling Pathways Regulating Steroidogenesis and Steroidogenic Acute Regulatory Protein Expression: More Complicated than We Thought. Mol. Endocrinol. 2005, 19, 2647-2659. [CrossRef]

150. Cochran, S.D.; Cole, J.B.; Null, D.J.; Hansen, P.J. Discovery of single nucleotide polymorphisms in candidate genes associated with fertility and production traits in Holstein cattle. BMC Genet. 2013, 14, 1-23. [CrossRef] [PubMed]

151. Yang, W.-C.; Li, S.-J.; Tang, K.-Q.; Hua, G.-H.; Zhang, C.-Y.; Yu, J.-N.; Han, L.; Yang, L.-G. Polymorphisms in the 5' upstream region of the FSH receptor gene, and their association with superovulation traits in Chinese Holstein cows. Anim. Reprod. Sci. 2010, 119, 172-177. [CrossRef] [PubMed]

152. Guay, C.; Madiraju, S.M.; Aumais, A.; Joly, É.; Prentki, M. A Role for ATP-Citrate Lyase, Malic Enzyme, and Pyruvate/Citrate Cycling in Glucose-induced Insulin Secretion. J. Biol. Chem. 2007, 282, 35657-35665. [CrossRef] [PubMed]

153. Glister, C.; Kemp, C.F.; Knight, P.G. Bone morphogenetic protein (BMP) ligands and receptors in bovine ovarian follicle cells: Actions of BMP-4, -6 and -7 on granulosa cells and differential modulation of Smad-1 phosphorylation by follistatin. Reproduction 2004, 127, 239-254. [CrossRef] [PubMed]

154. Knight, P.G.; Glister, C. TGF-beta superfamily members and ovarian follicle development. Reproduction 2006, 132, 191-206. [CrossRef]

155. Otsuka, F.; Yamamoto, S.; Erickson, G.F.; Shimasaki, S. Bone Morphogenetic Protein-15 Inhibits Follicle-stimulating Hormone (FSH) Action by Suppressing FSH Receptor Expression. J. Biol. Chem. 2001, 276, 11387-11392. [CrossRef] [PubMed]

156. Wilson, T.; Wu, X.-Y.; Juengel, J.L.; Ross, I.K.; Lumsden, J.M.; Lord, E.A.; Dodds, K.G.; Walling, G.A.; McEwan, J.C.; O'Connell, A.R.; et al. Highly Prolific Booroola Sheep Have a Mutation in the Intracellular Kinase Domain of Bone Morphogenetic Protein IB Receptor (ALK-6) That Is Expressed in Both Oocytes and Granulosa Cells. Biol. Reprod. 2001, 64, 1225-1235. [CrossRef]

157. Bornstein, S.; Rutkowski, H.; Vrezas, I. Cytokines and steroidogenesis. Mol. Cell. Endocrinol. 2004, 215, 135-141. [CrossRef] [PubMed]

158. Sirotkin, A.V. Cytokines: Signalling molecules controlling ovarian functions. Int. J. Biochem. Cell Biol. 2011, 43, 857-861. [CrossRef] [PubMed]

159. Bevers, M.; Dieleman, S.; Hurk, R.V.D.; Izadyar, F. Regulation and modulation of oocyte maturation in the bovine. Theriogenology 1997, 47, 13-22. [CrossRef]

160. Hansen, P. Embryonic mortality in cattle from the embryo's perspective. J. Anim. Sci. 2002, 80 (Suppl. 2), E33-E44. [CrossRef]

161. Yamashita, Y.; ShiMADA, M. The release of EGF domain from EGF-like factors by a specific cleavage enzyme activates the EGFR-MAPK3/1 pathway in both granulosa cells and cumulus cells during the ovulation process. J. Reprod. Deve. 2012, 58, 510-514. [CrossRef] [PubMed]

162. Hsieh, M.; Thao, K.; Conti, M. Genetic Dissection of Epidermal Growth Factor Receptor Signaling during Luteinizing HormoneInduced Oocyte Maturation. PLoS ONE 2011, 6, e21574. [CrossRef] [PubMed]

163. Lau, E.; Ze'ev, A.R. ATF2-at the crossroad of nuclear and cytosolic functions. J. Cell Sci. 2012, 125, 2815-2824. [CrossRef] [PubMed] 
164. Villa-Diaz, L.G.; Miyano, T. Activation of p38 MAPK During Porcine Oocyte Maturation. Biol. Reprod. 2004, 71, 691-696. [CrossRef]

165. Jamnongjit, M.; Gill, A.; Hammes, S.R. Epidermal growth factor receptor signaling is required for normal ovarian steroidogenesis and oocyte maturation. Proc. Natl. Acad. Sci. USA 2005, 102, 16257-16262. [CrossRef]

166. Kume, S.; Endo, T.; Nishimura, Y.; Kano, K.; Naito, K. Porcine SPDYA2 (RINGO A2) Stimulates CDC2 Activity and Accelerates Meiotic Maturation of Porcine Oocytes. Biol. Reprod. 2007, 76, 440-447. [CrossRef]

167. Dupré, A.; Haccard, O.; Jessus, C. Mos in the Oocyte: How to Use MAPK Independently of Growth Factors and Transcription to Control Meiotic Divisions. J. Signal. Transduct. 2011, 2011, 1-15. [CrossRef]

168. Lonergan, P.; Carolan, C.; Van Langendonckt, A.; Donnay, I.; Khatir, H.; Mermillod, P. Role of Epidermal Growth Factor in Bovine Oocyte Maturation and Preimplantation Embryo Development in Vitro. Biol. Reprod. 1996, 54, 1420-1429. [CrossRef]

169. Ding, J.; Foxcroft, G.R. Epidermal growth factor enhances oocyte maturation in pigs. Mol. Reprod. Dev. 1994, 39, 30-40. [CrossRef] [PubMed]

170. Zhang, M.; Ouyang, H.; Xia, G. The signal pathway of gonadotrophins-induced mammalian oocyte meiotic resumption. Mol. Hum. Reprod. 2009, 15, 399-409. [CrossRef]

171. Chakravarthi, V.P.; Ghosh, S.; Housami, S.M.; Wang, H.; Roby, K.F.; Wolfe, M.W.; Kinsey, W.H.; Rumi, M.K. ER $\beta$ regulated ovarian kisspeptin plays an important role in oocyte maturation. Mol. Cell. Endocrinol. 2021, 527, 111208. [CrossRef]

172. Gupta, A.; Tiwari, M.; Prasad, S.; Chaube, S.K. Role of Cyclic Nucleotide Phosphodiesterases During Meiotic Resumption from Diplotene Arrest in Mammalian Oocytes. J. Cell. Biochem. 2016, 118, 446-452. [CrossRef]

173. Jäger, R.; Russwurm, C.; Schwede, F.; Genieser, H.-G.; Koesling, D.; Russwurm, M. Activation of PDE10 and PDE11 Phosphodiesterases*. J. Biol. Chem. 2012, 287, 1210-1219. [CrossRef]

174. Conti, M.; Hsieh, M.; Zamah, A.M.; Oh, J.S. Novel signaling mechanisms in the ovary during oocyte maturation and ovulation. Mol. Cell. Endocrinol. 2012, 356, 65-73. [CrossRef] [PubMed]

175. Haccard, O.; Jessus, C. Oocyte Maturation, Mos and Cyclins-A Matter of Synthesis: Two Functionally Redundant Ways to Induce Meiotic Maturation. Cell Cycle 2006, 5, 1152-1159. [CrossRef] [PubMed]

176. Ye, Y.; Kawamura, K.; Sasaki, M.; Kawamura, N.; Groenen, P.; Gelpke, M.D.S.; Rauch, R.; Hsueh, A.J.; Tanaka, T. Kit ligand promotes first polar body extrusion of mouse preovulatory oocytes. Reprod. Biol. Endocrinol. 2009, 7, 26. [CrossRef] [PubMed]

177. Lowther, K.M.; Mehlmann, L.M. Embryonic Poly(A)-Binding Protein Is Required During Early Stages of Mouse Oocyte Development for Chromatin Organization, Transcriptional Silencing, and Meiotic Competencebiol. Biol. Reprod. 2015, 93, 43. [CrossRef]

178. Izard, M.K.; Vandenbergh, J.G. The Effects of Bull Urine on Puberty and Calving Date in Crossbred Beef Heifers. J. Anim. Sci. 1982, 55, 1160-1168. [CrossRef]

179. Vyas, S.; Briant, C.; Chemineau, P.; Le Danvic, C.; Nagnan-Le Meillour, P. Oestrus pheromones in farm mammals, with special reference to cow. Indian J. Anim. Sci. 2012, 82, 256-267.

180. Yoon, H.; Enquist, L.; Dulac, C. Olfactory Inputs to Hypothalamic Neurons Controlling Reproduction and Fertility. Cell 2005, 123, 669-682. [CrossRef] [PubMed]

181. Costa, R.B.; Camargo, G.M.; Diaz, I.D.; Irano, N.; Dias, M.M.; Carvalheiro, R.; Boligon, A.A.; Baldi, F.; Oliveira, H.N.; Tonhati, H.; et al. Genome-wide association study of reproductive traits in Nellore heifers using Bayesian inference. Genet. Sel. Evol. 2015, 47, 67. [CrossRef]

182. Melo, T.P.D.; De Camargo, G.M.F.; De Albuquerque, L.G.; Carvalheiro, R. Genome-wide association study provides strong evidence of genes affecting the reproductive performance of Nellore beef cows. PLoS ONE 2017, 12, e0178551. [CrossRef] [PubMed]

183. Ushizawa, K.; Takahashi, T.; Hosoe, M.; Ishiwata, H.; Kaneyama, K.; Kizaki, K.; Hashizume, K. Global gene expression analysis and regulation of the principal genes expressed in bovine placenta in relation to the transcription factor AP-2 family. Reprod. Biol. Endocrinol. 2007, 5, 17. [CrossRef]

184. Kramer, P.R.; Krishnamurthy, R.; Mitchell, P.J.; Wray, S. Transcription Factor Activator Protein-2 Is Required for Continued Luteinizing Hormone-Releasing Hormone Expression in the Forebrain of Developing Mice. Endocrinology 2000, 141, 1823-1838. [CrossRef] [PubMed]

185. Fortes, M.R.S.; Lehnert, S.A.; Bolormaa, S.; Reich, C.; Fordyce, G.; Corbet, N.J.; Whan, V.; Hawken, R.J.; Reverter, A. Finding genes for economically important traits: Brahman cattle puberty. Anim. Prod. Sci. 2012, 52, 143-150. [CrossRef]

186. Li, R.; Wu, S.-P.; Zhou, L.; Nicol, B.; Lydon, J.P.; Yao, H.H.-C.; DeMayo, F.J. Increased FOXL2 expression alters uterine structures and functions. Biol. Reprod. 2020, 103, 951-965. [CrossRef]

187. Matagne, V.; Kim, J.G.; Ryu, B.J.; Hur, M.K.; Kim, M.S.; Kim, K.; Park, B.S.; Damante, G.; Smiley, G.; Lee, B.J.; et al. Thyroid Transcription Factor 1, a Homeodomain Containing Transcription Factor, Contributes to Regulating Periodic Oscillations in GnRH Gene Expression. J. Neuroendocr. 2012, 24, 916-929. [CrossRef] [PubMed]

188. Daigneault, B.W.; Rajput, S.; Smith, G.W.; Ross, P.J. Embryonic POU5F1 is Required for Expanded Bovine Blastocyst Formation. Sci. Rep. 2018, 8, 7753. [CrossRef] [PubMed]

189. Chen, C.T.; Fernandez-Rhodes, L.; Brzyski, R.G.; Carlson, C.S.; Chen, Z.; Heiss, G.; North, K.E.; Woods, N.F.; Rajkovic, A.; Kooperberg, C.; et al. Replication of loci influencing ages at menarche and menopause in Hispanic women: The Women's Health Initiative SHARe Study. Hum. Mol. Genet. 2011, 21, 1419-1432. [CrossRef] [PubMed] 
190. Mesbah-Uddin, M. Genome-Wide Association Study with Imputed Whole-Genome Sequence Variants Including Large Deletions for Female Fertility in Three Nordic Dairy Breeds. Ph.D. Thesis, Aarhus University, Aarhus, Denmark, $2019 ;$; p. 84.

191. Gioia, L.; Barboni, B.; Turriani, M.; Capacchietti, G.; Pistilli, M.G.; Berardinelli, P.; Mattioli, M. The capability of reprogramming the male chromatin after fertilization is dependent on the quality of oocyte maturation. Reproduction 2005, 130, 29-39. [CrossRef] [PubMed] 